University of Nebraska - Lincoln

DigitalCommons@University of Nebraska - Lincoln

2005

\title{
"Sour gas" hydrothermal jarosite: ancient to modern acid-sulfate mineralization in the southern Rio Grande Rift
}

Virgil W. Lueth

New Mexico Bureau of Geology and Mineral Resources, New Mexico Tech

Robert O. Rye

U.S. Geological Survey, rrye@usgs.gov

Lisa Peters

New Mexico Bureau of Geology and Mineral Resources, New Mexico Tech

Follow this and additional works at: https://digitalcommons.unl.edu/usgsrye

Part of the Geochemistry Commons

Lueth, Virgil W.; Rye, Robert O.; and Peters, Lisa, "'Sour gas" hydrothermal jarosite: ancient to modern acidsulfate mineralization in the southern Rio Grande Rift" (2005). Geochemistry of Sulfate Minerals: A Tribute to Robert O. Rye. 10.

https://digitalcommons.unl.edu/usgsrye/10

This Article is brought to you for free and open access by the US Geological Survey at DigitalCommons@University of Nebraska - Lincoln. It has been accepted for inclusion in Geochemistry of Sulfate Minerals: A Tribute to Robert O. Rye by an authorized administrator of DigitalCommons@University of Nebraska - Lincoln. 


\title{
"Sour gas" hydrothermal jarosite: ancient to modern acid-sulfate mineralization in the southern Rio Grande Rift
}

\author{
Virgil W. Lueth ${ }^{\mathrm{a}, *}$, Robert O. Rye ${ }^{\mathrm{b}}$, Lisa Peters ${ }^{\mathrm{a}}$ \\ ${ }^{a}$ New Mexico Bureau of Geology and Mineral Resources, New Mexico Tech, 801 Leroy Place, Socorro, New Mexico 87801, United States \\ ${ }^{\mathrm{b}}$ United States Geological Survey, P.O. Box 25046, MS 963, Federal Center, Denver, Colorado 80225-0046, United States
}

Accepted 1 June 2004

\begin{abstract}
As many as 29 mining districts along the Rio Grande Rift in southern New Mexico contain Rio Grande Rift-type (RGR) deposits consisting of fluorite-barite \pm sulfide-jarosite, and additional RGR deposits occur to the south in the Basin and Range province near Chihuahua, Mexico. Jarosite occurs in many of these deposits as a late-stage hydrothermal mineral coprecipitated with fluorite, or in veinlets that crosscut barite. In these deposits, many of which are limestone-hosted, jarosite is followed by natrojarosite and is nested within silicified or argillized wallrock and a sequence of fluorite-barite \pm sulfide and late hematitegypsum. These deposits range in age from $\sim 10$ to $0.4 \mathrm{Ma}$ on the basis of ${ }^{40} \mathrm{Ar} /{ }^{39} \mathrm{Ar}$ dating of jarosite. There is a crude northsouth distribution of ages, with older deposits concentrated toward the south. Recent deposits also occur in the south, but are confined to the central axis of the rift and are associated with modern geothermal systems. The duration of hydrothermal jarosite mineralization in one of the deposits was approximately 1.0 my. Most $\Delta^{18} \mathrm{O}_{\mathrm{SO}_{4}}-\mathrm{OH}$ values indicate that jarosite precipitated between 80 and $240{ }^{\circ} \mathrm{C}$, which is consistent with the range of filling temperatures of fluid inclusions in late fluorite throughout the rift, and in jarosite $\left(180{ }^{\circ} \mathrm{C}\right)$ from Peña Blanca, Chihuahua, Mexico. These temperatures, along with mineral occurrence, require that the jarosite have had a hydrothermal origin in a shallow steam-heated environment wherein the low $\mathrm{pH}$ necessary for the precipitation of jarosite was achieved by the oxidation of $\mathrm{H}_{2} \mathrm{~S}$ derived from deeper hydrothermal fluids. The jarosite also has high trace-element contents (notably As and F), and the jarosite parental fluids have calculated isotopic signatures similar to those of modern geothermal waters along the southern rift; isotopic values range from those typical of meteoric water to those of deep brine that has been shown to form from the dissolution of Permian evaporite by deeply circulating meteoric water. Jarosite $\delta^{34} \mathrm{~S}$ values range from $-24 \%$ to $5 \%$, overlapping the values for barite and gypsum at the high end of the range and for sulfides at the low end. Most $\delta^{34} \mathrm{~S}$ values for barite are $10.6 \%$ to $13.1 \%$, and many $\delta^{34} \mathrm{~S}$ values for gypsum range from $13.1 \%$ to $13.9 \%$ o indicating that a component of aqueous sulfate was derived from Permian evaporites $\left(\delta^{34} \mathrm{~S}=12 \pm 2 \%\right.$ ). The requisite $\mathrm{H}_{2} \mathrm{SO}_{4}$ for jarosite formation was derived from oxidation of $\mathrm{H}_{2} \mathrm{~S}$ which was likely largely sour gas derived from the thermochemical reduction of Permian sulfate. The low $\delta^{34} \mathrm{~S}$ values for the precursor $\mathrm{H}_{2} \mathrm{~S}$ probably resulted from exchange deeper in the basin with the more abundant Permian $\mathrm{SO}_{4}^{2-}$ at $\sim 150$ to $200{ }^{\circ} \mathrm{C}$. Jarosite formed at shallow levels after the $\mathrm{pH}$ buffering capacity of the host rock (typically limestone) was neutralized by precipitation of earlier minerals. Some limestone-hosted deposits contain
\end{abstract}

* Corresponding author. Tel.: +1 505835 5140; fax: +1 5058356333.

E-mail address: vwlueth@nmt.edu (V.W. Lueth). 
caves that may have been caused by the low $\mathrm{pH}$ of the deep basin fluids due to the addition of deep-seated HF and other magmatic gases during periods of renewed rifting. Caves in other deposits may be due to sulfuric acid speleogenesis as a result of $\mathrm{H}_{2} \mathrm{~S}$ incursion into oxygenated groundwaters. The isotopic data in these "sour gas" jarosite occurrences encode a record of episodic tectonic or hydrologic processes that have operated in the rift over the last 10 my.

(C) 2004 Elsevier B.V. All rights reserved.

Keywords: Rio Grande Rift; Sour gas; Jarosite; Stable isotopes; ${ }^{40} \mathrm{Ar} r{ }^{39} \mathrm{Ar}$

\section{Introduction}

Jarosite, $\mathrm{KFe}_{3}\left(\mathrm{SO}_{4}\right)_{2}(\mathrm{OH})_{6}$, forms in highly acid and oxidizing environments (Stoffregen, 1993; Rye and Alpers, 1997). It is a relatively common mineral in the weathering zones of pyrite-bearing ore deposits (supergene jarosite). As a rare subtype of this environment, jarosite can form in saline lakes and playas from aqueous sulfate that is derived from the oxidation of pyrite and transported many kilometers by groundwater (sedimentary jarosite, Alpers et al., 1992). Jarosite can also form from the aqueous sulfate derived from the oxidation of $\mathrm{H}_{2} \mathrm{~S}$ in epithermal environments and hot springs commonly associated with volcanism (steam-heated jarosite, Rye et al., 1992; Rye and Alpers, 1997). As a subtype of the steam-heated environment, jarosite recently has been recognized to form in fluorite-barite \pm sulfide-jarosite deposits in the Rio Grande Rift, where aqueous sulfate is derived from the oxidation of sour gas in basin brines (sour gas jarosite, Lueth et al., 1998, 1999). This study presents a summary of geological, age, and stable-isotope relationships of significant sour gas jarosite occurrences in the southern Rio Grande Rift and Basin and Range province of northern Mexico. From this summary, we develop a general model for the formation of sour gas hydrothermal jarosite and discuss its potential significance with respect to understanding the tectonic history of the study area.

The structure and chemical composition of jarosite allows for the determination of age by potassium and argon dating techniques (K/Ar and $\left.{ }^{40} \mathrm{Ar} /{ }^{39} \mathrm{Ar}\right)$. In addition, the stable-isotope compositions of sulfur $\left(\delta^{34} \mathrm{~S}\right)$, hydrogen $(\delta \mathrm{D})$, and oxygen at the $\mathrm{OH}$ and $\mathrm{SO}_{4}$ crystallographic sites $\left(\delta^{18} \mathrm{O}_{\mathrm{OH}}\right.$, and $\left.\delta^{18} \mathrm{O}_{\mathrm{SO}_{4}}\right)$ can be determined. Information derived from the isotopic analysis of jarosite can provide significant insight into hydrothermal pro- cesses during mineralization, and into supergene processes during destruction of the sulfide-bearing deposits by weathering (Rye and Alpers, 1997; Rye et al., 2000). The principles of stable-isotope geochemistry of jarosite, which are similar to those for alunite (Rye et al., 1992) and have been discussed by Rye and Alpers (1997), represent the basis for the interpretation of the stable-isotope data presented in this paper. Sulfur isotopic data indicate the origin of the sulfur and can be used to estimate depositional temperatures of minerals when coexisting sulfides are present or information on aqueous $\mathrm{H}_{2} \mathrm{~S}$ is available. Hydrogen isotopic data can be used to identify water sources in hydrothermal systems and to provide paleoclimate information. Oxygen isotope data also can be used to trace the source of the water and oxygen during sulfide oxidation, as well as to determine the degree of exchange between aqueous sulfate and water. Oxygen isotopic values for the sulfate and the hydroxyl sites in jarosite can reflect the temperature of jarosite formation (Rye and Stoffregen, 1995).

\section{Geological framework}

\subsection{Rio Grande Rift-type deposits}

Fluorite-barite \pm sulfide-jarosite deposits and numerous smaller occurrences are relatively common along the margins of the Rio Grande Rift and extend into the Basin and Range tectonic province of northern Mexico. These deposits have similar mineralogical and geological features. McLemore and Lueth (1996) classified the deposits as Rio Grande Rift (RGR) barite-fluorite-galena deposits (herein referred to as RGR-type) to differentiate them from the classic Mississippi Valley-type (MVT), a desig- 
nation favored by earlier workers (Roedder et al., 1968; Putnam et al., 1983). A discussion of the geological features, criteria for differentiating them from those of MVT deposits, and possible origins are presented by McLemore et al. (1998).

As many as 29 mining districts containing RGRtype deposits have been recognized in southern New Mexico, and eight of them were investigated for this study (Fig. 1, Table 1). The La Mojina and Peña Blanca districts, which have deposits with characteristics similar to those of the RGR-type deposits from the Basin and Range province of northern Mexico, are also included. Overall, jarosite from 18 mines or prospects was analyzed. The northernmost deposits that we studied include the Portales, Snake Pit, Tip-Top, Barrett, TEAA, and Sunshine mines (Nos. 1-6) in the Hansonburg district. The southernmost deposit is in the Peña Blanca district, Chihuahua, Mexico, at the Margaritas uranium deposit approximately $150 \mathrm{~km}$ south of the deposit at Mina la Mojina. Two mines (Bluestar and Heibert) and one prospect (South prospect) in the Bishop Cap district were studied along with jarosite-bearing deposits in the North Franklin district that include the Schneider deposits and two orebodies (north and south) at the Copiapo jarosite mine. Single deposits in the Potrillo Mountains (EPM claims) and Tonuco Mountain districts (San Diego Mountain) in New Mexico are also included in this paper.

\subsection{Regional setting}

The RGR-type deposits studied (Fig. 1) are related to extensional tectonism in the Rio Grande Rift and the southern Basin and Range tectonic provinces. The southern boundary of the rift remains undefined and merges with the Basin and Range to the south, although many workers have cited a curve in the rift that trends toward the Big Bend region of Texas (Henry et al., 1983; Keller and Cather, 1994). Most of the deposits studied are located on the margins of structural highs (McLemore et al., 1998), and many are confined to the north-south-trending mountain-range boundary faults. Analogously, modern geothermal systems within the rift are located in similar structural settings (Witcher, 1988).

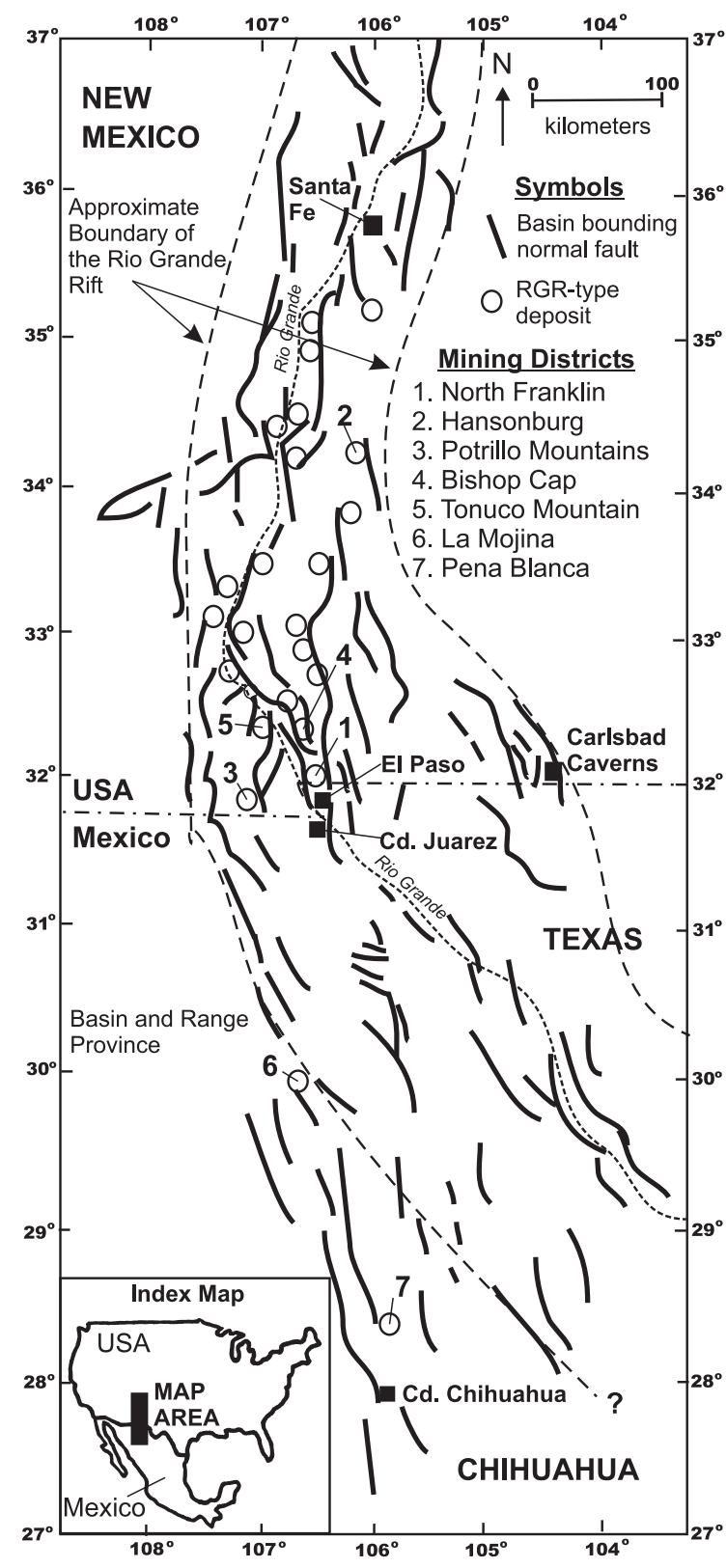

Fig. 1. Location and distribution of Rio Grande Rift-type deposits, Carlsbad Caverns in southern New Mexico, and similar types of deposits in the Basin and Range province of northern Mexico. Deposits that contain jarosite reported in this study are labeled. Map modified from Keller et al. (1990) and Henry et al. (1983).

\subsection{Geological features of the deposits}

RGR-type mineralization in this region occurs in mountain ranges that consist of tilted fault blocks in 
Table

Stable-isotope values for sulfates and sulfides, calculated waters in equilibrium with sulfates, and ${ }^{40} \mathrm{Ar} r{ }^{39} \mathrm{Ar}$ ages for jarosite

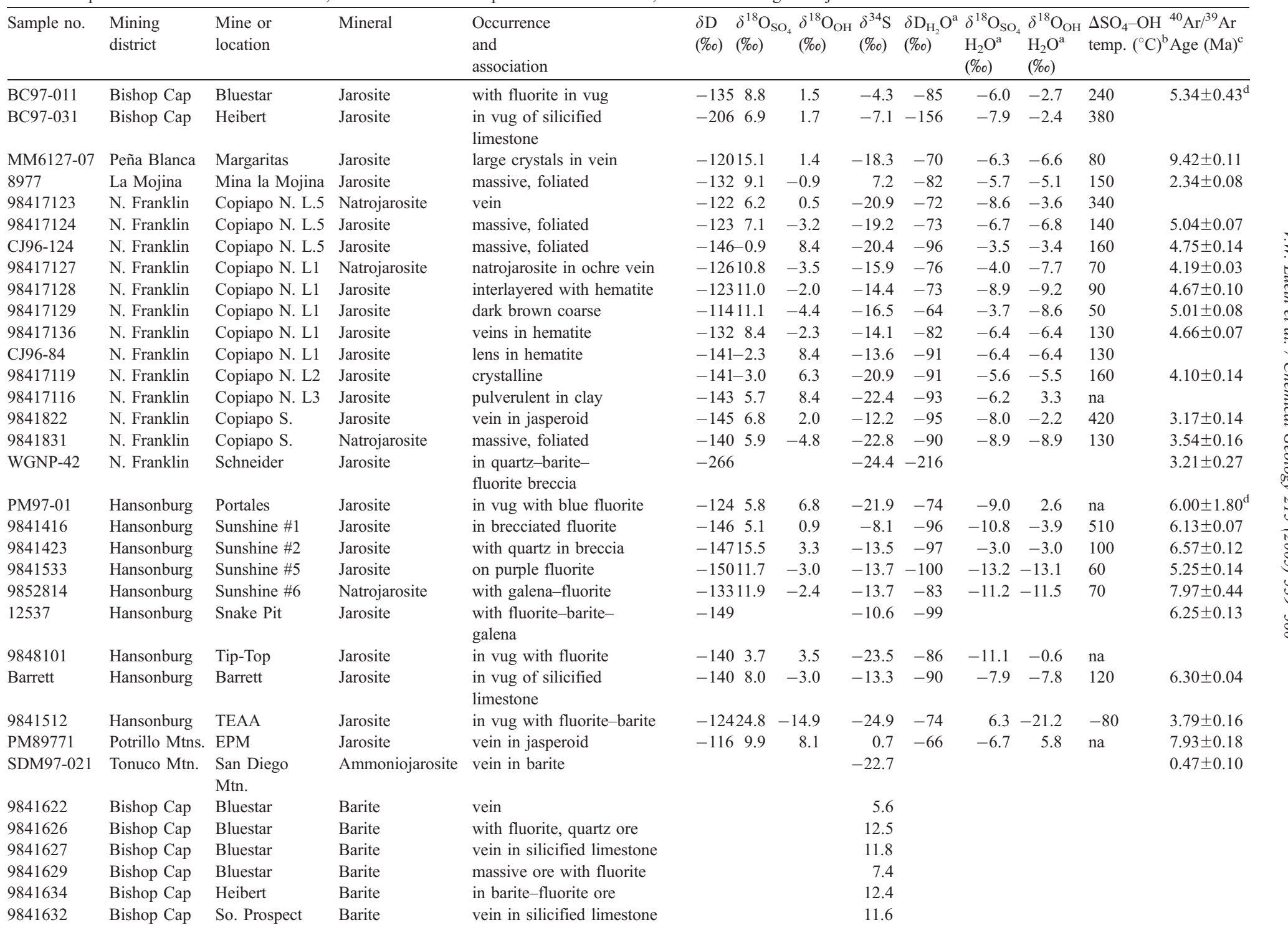

.




\begin{tabular}{|c|c|c|c|c|c|c|}
\hline 9841812 & N. Franklin & Copiapo S. & Barite & in jarosite-quartz breccia & 12.9 & 8.6 \\
\hline 9841713 & N. Franklin & Schneider & Barite & in quartz-fluorite-galena ore & & -2.0 \\
\hline 984771 & Hansonburg & Desert Rose & Barite & with quartz and fluorite & & 11.5 \\
\hline 9841541 & Hansonburg & Mex-Tex & Barite & with quartz and fluorite & & 11.2 \\
\hline 9841561 & Hansonburg & Royal Flush & Barite & with blue fluorite & & 11.7 \\
\hline 12354 & Hansonburg & Snake Pit & Barite & $\begin{array}{l}\text { with fluorite and silicified } \\
\text { limestone }\end{array}$ & & 10.6 \\
\hline 9841414 & Hansonburg & Sunshine \#1 & Barite & large crystals with fluorite & & 12.5 \\
\hline 9841425 & Hansonburg & Sunshine \#2 & Barite & with galena and quartz & & 11.8 \\
\hline 9841427 & Hansonburg & Sunshine \#2 & Barite & with hematite & & 12.4 \\
\hline 98414210 & Hansonburg & Sunshine \#2 & Barite & with fluorite, pyrite, sphalerite & & 12.4 \\
\hline 9841432 & Hansonburg & Sunshine \#3 & Barite & with galena, fluorite, gypsum & & 12.4 \\
\hline 9841443 & Hansonburg & Sunshine \#4 & Barite & with quartz and fluorite & & 12.3 \\
\hline 9841444 & Hansonburg & Sunshine \#4 & Barite & with hematite and gypsum & & 12.9 \\
\hline 9841531 & Hansonburg & Sunshine \#5 & Barite & with jarosite, quartz, fluorite & & 12.5 \\
\hline 9852814 & Hansonburg & Sunshine \#6 & Barite & with fluorite, galena, jarosite & & 12.1 \\
\hline 9848101 & Hansonburg & Tip-Top & Barite & with fluorite and jarosite & & 12.2 \\
\hline 9841521 & Hansonburg & Tip-Top & Barite & with fluorite and jarosite & & 12.5 \\
\hline PM89711 & Potrillo Mtns. & w. prospect & Barite & in jasperoid & & 13.1 \\
\hline GM421 & Gonzales & So. Prospect & Barite & with fluorite & & 10.6 \\
\hline CJ96-172 & N. Franklin & Copiapo N. & Gypsum & vein in halloysite clay & & -0.1 \\
\hline 98417142 & N. Franklin & Copiapo N. & Gypsum & vein in halloysite clay & 10.1 & 1.0 \\
\hline CJ96-82 & N. Franklin & Copiapo N. L1 & Gypsum & (selenite) with hematite & 10.9 & -11.8 \\
\hline 98417126 & N. Franklin & Copiapo N. L1 & Gypsum & (selenite) with hematite & 13.7 & -0.9 \\
\hline BW9724-77 & Hansonburg & Mex-Tex & Gypsum & with pyrite-jarosite & & -7.2 \\
\hline 9841412 & Hansonburg & Sunshine \#1 & Gypsum & massive in cave fill & & 13.1 \\
\hline 9841421 & Hansonburg & Sunshine \#2 & Gypsum & massive in cave fill & & 13.9 \\
\hline 9841425 & Hansonburg & Sunshine \#2 & Gypsum & $\begin{array}{l}\text { in cave with barite, } \\
\text { fluorite, galena }\end{array}$ & & 21.9 \\
\hline 98414210 & Hansonburg & Sunshine \#2 & Gypsum & with sphalerite and pyrite & & 13.5 \\
\hline 9841433 & Hansonburg & Sunshine \#3 & Gypsum & with galena, fluorite, barite & & 13.5 \\
\hline 9841442 & Hansonburg & Sunshine \#4 & Gypsum & $\begin{array}{l}\text { in small cave with barite, } \\
\text { galena }\end{array}$ & & 2.1 \\
\hline 9852811 & Hansonburg & Sunshine \#6 & Gypsum & pod & & 3.8 \\
\hline 9841524 & Hansonburg & Tip-Top & Gypsum & $\begin{array}{l}\text { crystals in vug with } \\
\text { barite, fluorite }\end{array}$ & & -5.0 \\
\hline Barrett & Hansonburg & Barrett & Gypsum & with jarosite & & 0.0 \\
\hline VC97-01 & N. Franklin & Vinton Canyon & Gypsum & on pyrite (Devonian Percha Sh) & & -7.2 \\
\hline Yeso & Hansonburg & Hwy 380 & Gypsum & Yeso Formation (Permian) & 13.0 & 7.1 \\
\hline 9841628 & Bishop Cap & Bluestar & Pyrite & in massive barite & & -5.4 \\
\hline 98416210 & Bishop Cap & Bluestar & Pyrite & with barite and fluorite & & -5.1 \\
\hline 9841631 & Bishop Cap & So. Prospect & Pyrite & with barite & & -3.8 \\
\hline VC97-03 & N. Franklin & Vinton Canyon & Pyrite & in Devonian Percha Shale & & -3.0 \\
\hline 98414210 & Hansonburg & Sunshine \#2 & Pyrite & with barite, fluorite, sphalerite & & -23.1 \\
\hline $9841446 a$ & Hansonburg & Sunshine \#4 & Pyrite & with quartz & & -13.2 \\
\hline
\end{tabular}


Table 1 (continued)

\begin{tabular}{|c|c|c|c|c|c|c|c|c|}
\hline Sample no. & $\begin{array}{l}\text { Mining } \\
\text { district }\end{array}$ & $\begin{array}{l}\text { Mine or } \\
\text { location }\end{array}$ & Mineral & $\begin{array}{l}\text { Occurrence } \\
\text { and association }\end{array}$ & $\begin{array}{l}\delta \mathrm{D} \\
(\% \circ)\end{array}$ & $\begin{array}{l}\delta^{18} \mathrm{O}_{\mathrm{SO}_{4}} \\
(\% \circ)\end{array}$ & $\begin{array}{l}\delta^{18} \mathrm{O}_{\mathrm{OH}} \\
(\% \circ)\end{array}$ & $\begin{array}{l}\delta^{34} \mathrm{~S} \\
(\% 0)\end{array}$ \\
\hline $9841446 b$ & Hansonburg & Sunshine \#4 & Pyrite & with gypsum & & & & -26.6 \\
\hline 9841447 & Hansonburg & Sunshine \#4 s. & Pyrite & with quartz & & & & -9.9 \\
\hline 9848101 & Hansonburg & Tip-Top & Pyrite & in silicified limestone & & & & -12.6 \\
\hline 9841843 & N. Franklin & Schneider & Pyrite & in silicified limestone & & & & -18.2 \\
\hline 984771 & Hansonburg & Desert Rose & Galena & with barite and fluorite & & & & -15.5 \\
\hline 11795 & Hansonburg & Mex-Tex & Galena & with barite, fluorite, sphalerite & & & & -12.6 \\
\hline 9841542 & Hansonburg & Mex-Tex & Galena & with barite & & & & -14.0 \\
\hline 12345 & Hansonburg & Snake Pit & Galena & with barite & & & & -15.4 \\
\hline 9841413 & Hansonburg & Sunshine \#1 & Galena & with barite, fluorite & & & & -15.7 \\
\hline 9841425 & Hansonburg & Sunshine \#2 & Galena & with barite, fluorite, gypsum & & & & -15.5 \\
\hline 9841432 & Hansonburg & Sunshine \#3 & Galena & with barite, fluorite, quartz & & & & -16.2 \\
\hline 9841433 & Hansonburg & Sunshine \#3 & Galena & with fluorite and barite & & & & -16.1 \\
\hline 9841443 & Hansonburg & Sunshine \#4 & Galena & with barite and gypsum & & & & -14.1 \\
\hline 9852814 & Hansonburg & Sunshine \#6 & Galena & with barite and fluorite & & & & -15.3 \\
\hline 9841523 & Hansonburg & Tip-Top & Galena & with barite and fluorite & & & & -14.0 \\
\hline 11795 & Hansonburg & Mex-Tex & Sphalerite & with chalcopyrite & & & & -26.4 \\
\hline 98414210 & Hansonburg & Sunshine \#2 & Sphalerite & with barite, fluorite, pyrite & & & & -11.3 \\
\hline 9632 & Hansonburg & Mex-Tex & Chalcopyrite & with sphalerite & & & & -13.8 \\
\hline 9841447 & Hansonburg & Sunshine \#4 & Chalcopyrite & with pyrite and quartz & & & & -13.1 \\
\hline CJ96-82 & Copiapo & Copiapo N. L1 & Hematite & with gypsum & & & $-3.0^{\mathrm{e}}$ & \\
\hline 98417126 & Copiapo & Copiapo N. L1 & Hematite & with gypsum & & & $-3.4^{\mathrm{e}}$ & \\
\hline 98417139 & Copiapo & Copiapo N. L1 & Hematite & with gypsum & & & $0.4^{\mathrm{e}}$ & \\
\hline
\end{tabular}

Hydrogen and oxygen isotope data presented in permil (\%o) relative to SMOW. Sulfur isotope data presented in permil relative to CDT.

${ }^{\text {a }}$ Calculated values for waters in equilibrium with jarosite at $130{ }^{\circ} \mathrm{C}$ using experimentally derived equation (Rye and Stoffregen, 1995).

${ }^{b}$ Temperatures $\left({ }^{\circ} \mathrm{C}\right)$ for jarosite are calculated from $\Delta^{18} \mathrm{O}_{\mathrm{SO}-\mathrm{OH}}$ values using experimentally derived equation (Rye and Stoffregen, 1995).

c Age spectra and data tables available from Lueth et al. (2004)

${ }^{\mathrm{d}}$ Represents sample with some problematic age considerations.

e $\delta^{18} \mathrm{O}$ of hematite. 
which Paleozoic carbonates predominate and rest unconformably on a basement of Proterozoic granites and metamorphic rocks. To the south, and on the western margins of the rift, Tertiary volcanic rocks commonly cap the ranges. The mineralization in rhyolite volcanics at Peña Blanca has features in common with RGR-type mineralization that occurs in the Basin and Range province west of the rift. In this work, Peña Blanca is considered to be an RGR-type deposit.

Carbonate rocks of Ordovician through Pennsylvanian age dominate the Paleozoic depositional history. The carbonates are capped by a thick section of Permian evaporites. Organic-rich rocks are common throughout the Paleozoic section, and some have been identified as hydrocarbon sourcerocks (e.g., the Devonian Percha Shale). Many of the limestone units are fetid, and hydrocarbon has been identified in a number of oil and gas wells drilled in the rift basins. Exploration for oil has increased in the rift basins during recent years, greatly enhancing our understanding of these basins (Keller and Cather, 1994). Some of these exploration wells produce geothermal waters (Summers, 1976).

Not all RGR-type deposits are confined to the limestones. Some deposits are localized at bedding or intrusive contacts, shear zones, and solution cavities in a wide range of rock types (McLemore et al., 1998). RGR-type mineralization along the rift is observed in faults and fracture systems in Proterozoic rocks, although the age of these deposits is speculative. Primary igneous fluorite grains have been noted in A-type Proterozoic granite and granite pegmatites (Shannon, 1994).

Most of the deposits are characterized by variable proportions of fluorite and barite, with minor to absent sulfides that precipitated as openspace fillings in veins, breccias, and solution cavities, or by replacement. The sulfide minerals are predominantly galena with lesser amounts of pyrite, sphalerite, and chalcopyrite. The Hansonburg deposits differ from most others in containing a greater abundance of sulfides. Silicification is the most common type of wallrock alteration and in most deposits is pervasive. A number of deposits contain cave development in what was the deeper plumbing system of their limestone host rocks. A limited number of orebodies at Hansonburg display features of sulfuric acid speleogenesis that include irregular cavern development and copious amounts of gypsum. Multiple episodes of mineralization are documented at Hansonburg (Lueth et al., 2000), and the timing of cave formation between preexisting karst (Putnam et al., 1983), deep basin-brine dissolution, and sulfuric acid speleogenesis remains ambiguous.

Notable exceptions to the common features discussed above are the deposits in the North Franklin district at the Copiapo jarosite mine. Jarosite is the dominant mineral in veins surrounded by a clay (halloysite) alteration envelope in the north orebody. Fluorite is abundant but is exceptionally fine-grained and mixed with jarosite. The south orebody is more typical in that it has extensive silicification associated with jarosite mineralization. Barite is present but only in small amounts and on the margin of the south orebody, which was originally thought continuous with the northern ores prior to recent dating (Lueth et al., 1998, 2004).

Homogenization temperatures of fluid inclusions in fluorite in all of the deposits studied range from 95 to $346{ }^{\circ} \mathrm{C}$, with salinities between 0 and 20 equivalent weight percent $\mathrm{NaCl}$ (McLemore et al., 1998). However, the vast majority of homogenization temperatures range between 120 and $225{ }^{\circ} \mathrm{C}$, with variable salinities. Putnam et al. (1983) reported the presence of hydrocarbons in fluid inclusions in fluorite from Hansonburg.

\section{Hydrothermal jarosite mineralization}

Hydrothermal jarosite has been found in a surprisingly large number of RGR-type deposits even though only a few previous workers mention the presence of the mineral in published reports (Dunham, 1935; Jenkins, 1977). In the majority of deposits, the jarosite is of limited distribution and generally occurs late in the mineralization sequence as inclusions and coatings in and on fluorite, or in veins that crosscut barite. Most deposits also contain gypsum and hematite. In these deposits, a characteristic paragenesis is typically present: (1) wallrock dissolution or alteration; (2) fluoritebarite-sulfide; \pm (3) hematite-gypsum; \pm (4) jarosite; 
$\pm(5)$ natrojarosite. Larger deposits with abundant jarosite seem to reflect more complex hydrothermal histories (e.g., Hansonburg; Lueth et al., 2000) in which multiple episodes of hydrothermal jarosite precipitation are recognized and may correlate with multiple episodes of fluorite mineralization. In the few deposits that contain sulfides, supergene jarosite is also present, but it is texturally, temporally, and isotopically distinct from hydrothermal varieties. Although we discuss the textural features of supergene jarosite in some deposits, no data for supergene jarosite are presented in this paper.

Hydrothermal jarosite occurs as macroscopic crystals in vugs, as inclusions along growth planes in fluorite, or as vein fillings that cut ore minerals (Fig. 2). The crystals commonly are euhedral and up to $3 \mathrm{~mm}$ in size, but those at Peña Blanca, Mexico, attain the phenomenal size of more than 3 $\mathrm{cm}$ (Goodell et al., 1999). Some jarosite has a micaceous habit with its foliation parallel to fault slickensides, as at the Copiapo north and Mina la Mojina deposits.

Paragenetic relationships between hydrothermal and supergene jarosite are readily apparent when both are present. Supergene jarosite is typically pulverulent and forms coatings over previously precipitated minerals. Such jarosite is commonly contaminated with quartz or clay. The relative lack of sulfide mineralization in most RGR-type deposits limits the potential for the formation of supergene jarosite.

Two deposits in the rift, each containing large amounts of jarosite, have been studied in detail and will be the subject of separate forthcoming papers. The largest jarosite deposit in New Mexico, the Copiapo Jarosite mine, is the "type deposit" for sour gas hydrothermal jarosite. Dunham (1935) and Berliner (1949) first described the geological features of this unique deposit, which was originally mined for paint pigment. Recognition of the hydrothermal nature of the deposit was first reported by Lueth and Goodell (1996) and was further developed by Lueth et al. (1998, 1999). The Hansonburg deposit has been the most extensively studied of the RGR-type deposits in the rift (Roedder et al., 1968; Allmendinger, 1975; Putnam et al., 1983; Norman et al., 1985; Böhlke and Irwin, 1992; Lueth and Heizler, 1997; Lueth et al., 2000). The other, much smaller, deposits along the rift have been correspondingly less well documented, although all were summarized in McLemore et al. (1998).
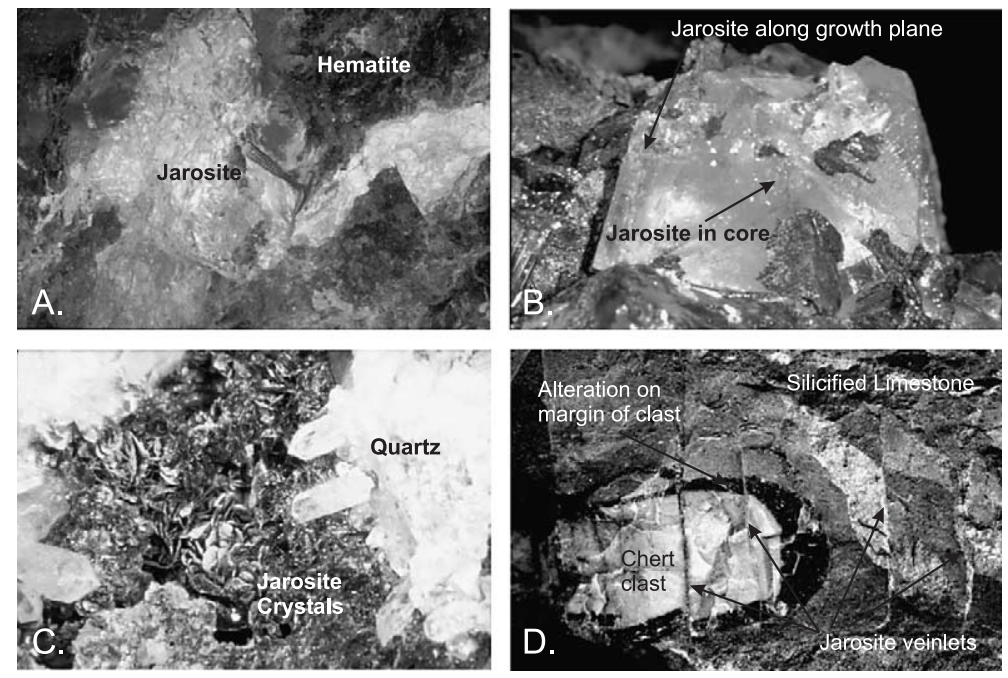

Fig. 2. Photographs of jarosite occurrences in barite-fluorite deposits. (A). Massive jarosite-hematite primary mineralization at the Copiapo jarosite mine; note rock hammer at center for scale. (B). Inclusions in the core and along growth planes in fluorite, Sunshine Tunnels, Hansonburg. Fluorite crystal is $1.5 \mathrm{~cm}$ across. (C). Jarosite crystals, 2 to $3 \mathrm{~mm}$ across, in a vug of quartz, Royal Flush mine, Hansonburg. (D). Silicified limestone and chert clast with veinlets of jarosite that crosscut clasts and host rock, Copiapo south orebody. Width of field of view is $10 \mathrm{~cm}$. 


\section{4. ${ }^{40} \mathrm{Ar} /{ }^{39} \mathrm{Ar}$ dating of jarosite}

Relatively few samples of jarosite have been dated by the $\mathrm{K} / \mathrm{Ar}$ or ${ }^{40} \mathrm{Ar} /{ }^{39} \mathrm{Ar}$ methods and, until recently, none of these have been of hydrothermal jarosite. Sillitoe and McKee (1996) and Vasconcelos et al. (1994) published the ages of a few supergene jarosite samples from Chile and Goldfield, Nevada. They found that ${ }^{39} \mathrm{Ar}$ recoil, excess Ar, and low-temperature, diffusive radiogenic Ar loss were not significant problems in the dating of jarosite.

Handpicked mineral separates of jarosite, natrojarosite, and plumbojarosite were confirmed by Xray powder diffraction at the New Mexico Bureau of Geology and Mineral Resources X-ray Diffraction Laboratory. The samples were prepared and analyzed using methods summarized by Lueth et al. (2004).

The jarosite samples in this study yielded fairly well-defined age spectra (Lueth et al., 2004). As with the samples analyzed by Sillitoe and McKee (1996) and Vasconcelos et al. (1994), ${ }^{39}$ Ar recoil, excess Ar, and Ar loss did not seem to be a significant problem. Possible contamination with older clays and poor gas cleanup resulting in nonlinear isotopic regressions were the only sample-related or analytical problems revealed by these analyses. The results of Ar dating of hydrothermal jarosite in this study are generally of high precision, possibly because of the high degree of crystal perfection, compositional purity, and larger grain sizes inherent to hydrothermal jarosite.

Representative age spectra from the Copiapo jarosite mine (Fig. 3) illustrate the nature of the Ar age spectra obtained for the Ar ages (Table 1). The relative precision of the analysis seems to be a function of sample purity, composition, and crystal size, as is illustrated by the ${ }^{40} \mathrm{Ar} /{ }^{39} \mathrm{Ar}$ age spectra for a coarse-grained jarosite (98417129, Copiapo mine, north orebody) and a fine-grained natrojarosite vein (9841831, Copiapo mine, south orebody).

Crosscutting relationships between different ages of jarosite mineralization are apparent within the Copiapo north orebody. Crystalline jarosite of the main ore mass and crosscutting jarosite-natrojarosite ochre veins range from $5.01 \pm 0.08$ to $4.19 \pm 0.34$ $\mathrm{Ma}$, respectively. The ages clearly correspond to the paragenetic sequencing observed in the ores. The
5.01 Ma sample (98417129) is pure jarosite of coarse grain size, whereas the younger sample (98417127) is from an ochre vein that crosscuts coarse jarosite. We interpret these relationships to indicate a $\sim 1.0$ my time span for mineralization in this portion of the north orebody of the deposit (Lueth et al., 1999). Age dates from the separate south orebody indicate mineralization occurred during a separate episode around 3.2 to $3.5 \mathrm{Ma}$.

Ages for hydrothermal jarosite mineralization range from around $9.42 \mathrm{Ma}$ at Peña Blanca, Mexico to $0.47 \mathrm{Ma}$ at San Diego Mountain, New Mexico. The distribution of jarosite ages in the study area reveals a crude spectrum of ages that corresponds to inferred rift development from south to north. The greatest number of old ages $(>7.5$ Ma) for jarosite are in the southernmost portion of New Mexico (Potrillo, Bishop Cap-Heibert mine) and Mexico (Peña Blanca), with the Sunshine No. 6 mine at Hansonburg an exception. There is also a spectrum of ages for jarosite along transects across the rift. Older ages are nearer the margins of the rift and progressively young toward the rift axis (e.g., Bishop Cap district to Tonuco Mountain district in New Mexico). The youngest date, 0.4 $\mathrm{Ma}$ at the San Diego Mountain deposit, is consistent with the observation of recent geothermal systems nearby to the south at Radium Springs and in the subsurface to the north at Rincon (Witcher, 1998).

Although a spectrum of ages is observed from the deposits throughout the study area (Fig. 4), a number of geographically separated deposits share similar ages. The oldest shared age, about 8.0 Ma, occurs at Hansonburg (Sunshine No. 6) and the EPM claims in the Potrillo Mountains districts. Another cluster of ages in the RGR-type deposits corresponds to mineralization from 6.5 to $6.1 \mathrm{Ma}$ noted at Hansonburg (Royal Flush, Snake Pit, Portales, and Sunshine Tunnels). The mineralization during this time period spans the entire north-south geographic range $(4 \mathrm{~km})$ of the Hansonburg district. As previously mentioned, the Copiapo deposit (Copiapo $\mathrm{N}$ in Table 1) reveals a spectrum of ages, from 5.1 to $4.1 \mathrm{Ma}$, in the north orebody. Jarosite from the Sunshine No. 5 deposit $(5.27 \mathrm{Ma})$ in the Hansonburg district also formed at nearly the same time as the Copiapo 

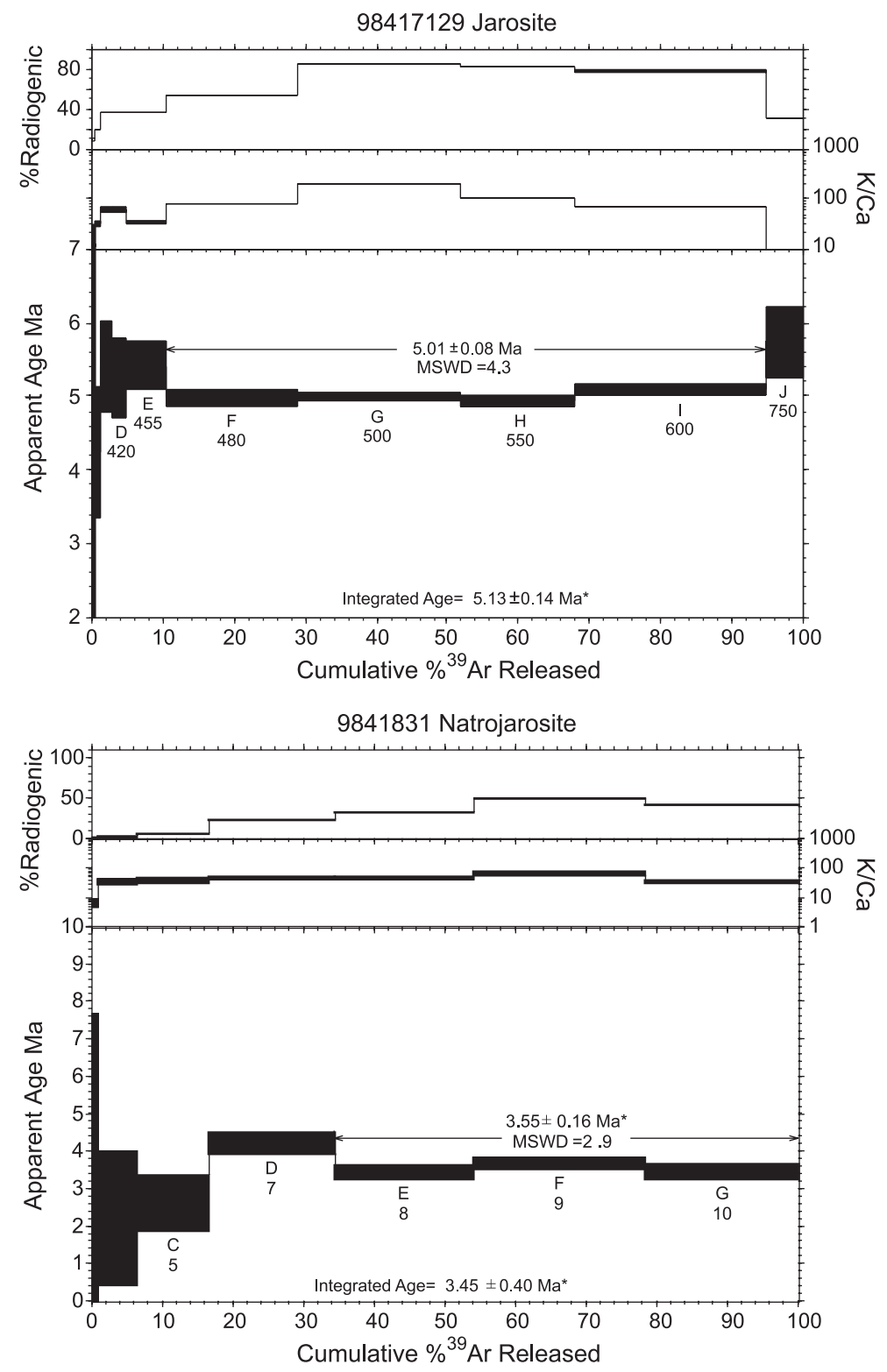

Fig. $3 .{ }^{40} \mathrm{Ar} /{ }^{39} \mathrm{Ar}$ age spectra for two samples from the Copiapo jarosite mine. The upper spectrum (sample 98417129) is for a pure, coarsely crystalline jarosite from the north orebody (Fig. 2A). The lower spectrum (sample 9841831) is from fine-grained natrojarosite veinlets that cut silicified limestone (Fig. 2D).

north samples. The south orebody at Copiapo (Copiapo $\mathrm{S}$ in Table 1) and the Schneider claims, approximately $4 \mathrm{~km}$ north, share an age of 3.2 Ma with a similar, although slightly older, age of mineralization (3.8 Ma) observed at Hansonburg (TEAA deposits).

\section{Stable-isotope analyses of jarosite}

Jarosite, a member of the alunite group, contains both sulfate and hydroxyl sites. The isotope compositions of sulfur and oxygen in the sulfate site and hydrogen and oxygen in the $\mathrm{OH}$ site in jarosite can be 


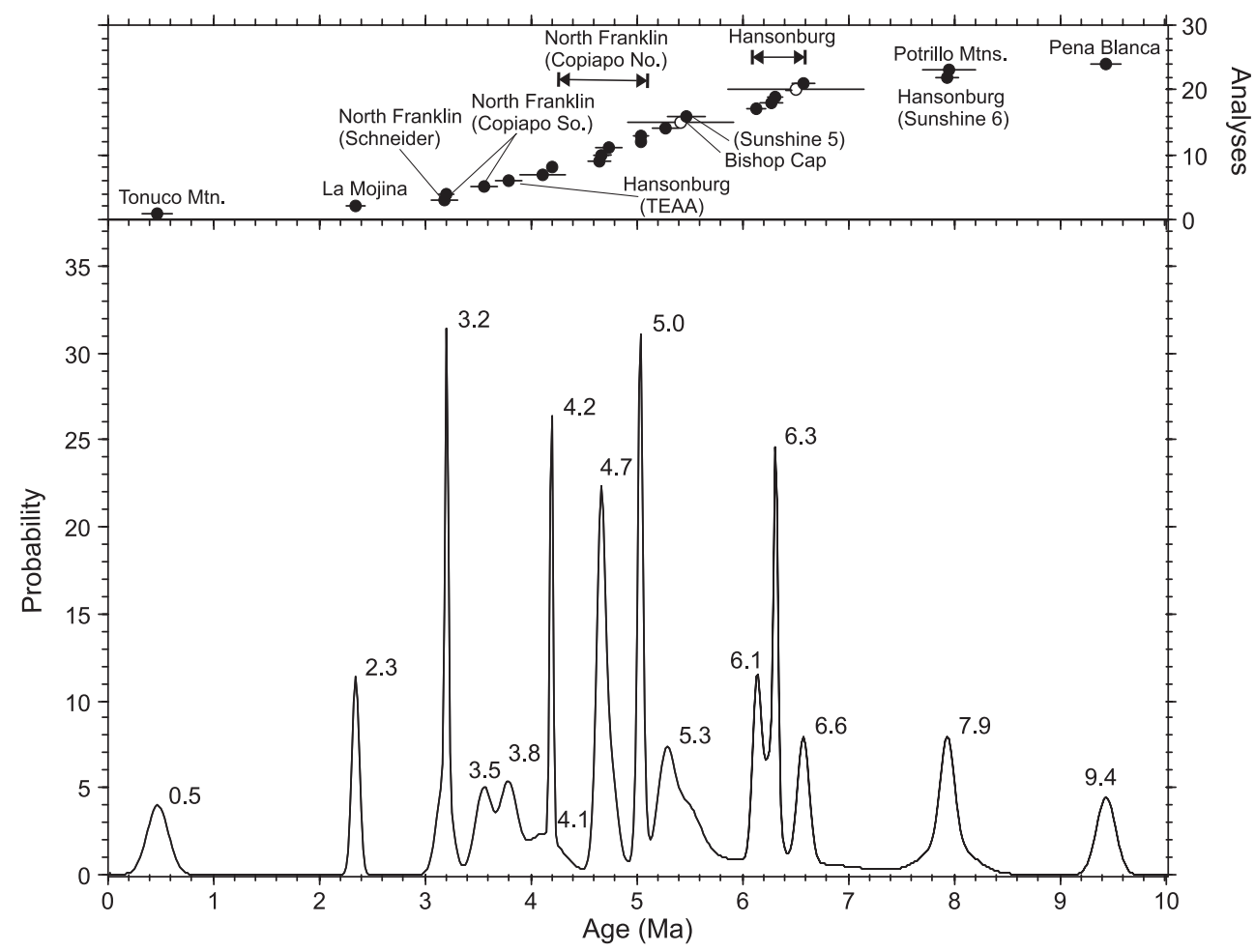

Fig. 4. Age-probability diagram for jarosite age dates in the study area. Open circles represent ${ }^{40} \mathrm{Ar} /{ }^{39} \mathrm{Ar}$ age analyses of poor quality (Lueth et al., 2004). Points correspond to age dates from individual deposits within districts, with mine names in parentheses. Ages presented in the lower portion diagram will not necessarily correspond to individual ages in Table 1. Calculation of the age-probability curve was accomplished using the techniques described by Deino and Potts (1992).

determined by the techniques described for alunite by Wasserman et al. (1992). All samples of jarosite were coarse enough to be handpicked from associated barite and fluorite. For $\delta^{18} \mathrm{O}_{\mathrm{SO}_{4}}$ and $\delta^{34} \mathrm{~S}$ analyses, jarosite is selectively dissolved in heated solution of $0.5 \mathrm{~N} \mathrm{NaOH}$. The filtered solution is titrated with $\mathrm{HCl}$, sulfate is precipitated as $\mathrm{BaSO}_{4}$ (by a method that prevents coprecipitation of $\mathrm{Fe}(\mathrm{OH})_{3}$ ) and is subsequently analyzed for $\delta^{34} \mathrm{~S}$ and $\delta^{18} \mathrm{O}_{\mathrm{SO}_{4}}$ by conventional or continuous flow mass spectrometry. $\delta \mathrm{D}$ analyses were preformed by conventional mass spectrometry on water derived from jarosite by inductively coupled stepwise heating decomposition that minimized $\mathrm{SO}_{2}$ and $\mathrm{H}_{2} \mathrm{SO}_{4}$ production and formation of $\mathrm{K} \pm \mathrm{Na}$ oxides. Some $\delta \mathrm{D}$ analyses were also made directly by continuous flow mass spectrometry without prior treatment. $\delta^{18} \mathrm{O}_{\mathrm{OH}}$ analyses were performed using a total fluorination method as described by Wasserman et al. (1992). Sulfur isotope analyses of barite, gypsum (after dehydration), and sulfides were made by combustion continuous flow mass spectrometry (Giesemann et al., 1994). Oxygen isotope analyses of barite and gypsum (after dehydration) were made by pyrolysis continuous flow mass spectrometry. Hydrogen and oxygen isotope data are presented in permil $(\%)$ relative to SMOW and sulfur isotope data are presented in permil relative to CDT.

Stable-isotope data for jarosite, gypsum, and barite, the calculated jarosite fluid compositions, and short descriptions of the samples are presented in Table 1. These data are also plotted in Figs. 5 and 6. Fig. 5 also shows data for anhydrite from the Permian Yeso Formation evaporite (gypsum), and the ranges of values for hydrothermal sulfides in the study area. Tie lines in Fig. 5 connect $\delta^{18} \mathrm{O}_{\mathrm{SO}_{4}}$ and $\delta^{18} \mathrm{O}_{\mathrm{OH}}$ values from the same samples. In addition to mineral data, Fig. 6 shows the calculated composition of jarosite parental fluids and the published compositions of geothermal and modern groundwater in the rift, and 


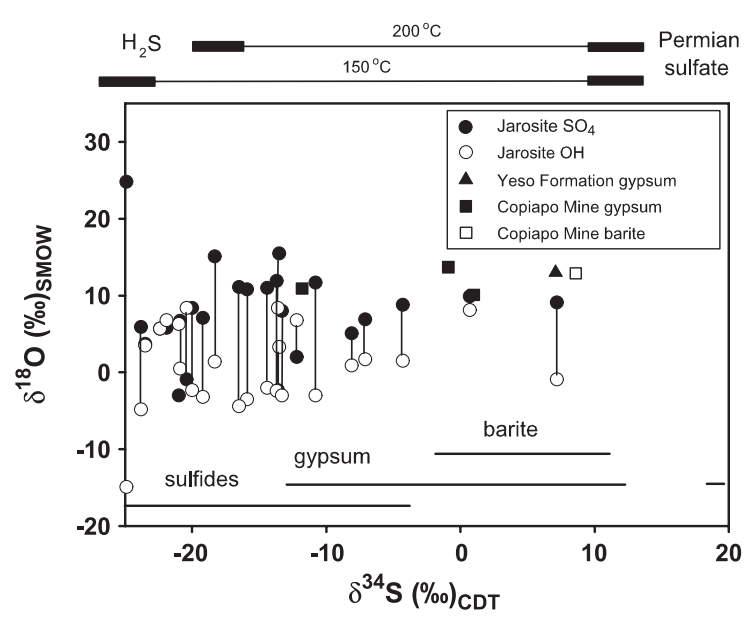

Fig. 5. Diagram showing $\delta^{34} \mathrm{~S}-\delta^{18} \mathrm{O}_{\mathrm{SO}_{4}}-\delta^{18} \mathrm{O}_{\mathrm{OH}}$ for jarosite, barite, and gypsum from southern New Mexico and northern Mexico. The lines connect $\delta^{18} \mathrm{O}_{\mathrm{SO}_{4}-} \delta^{18} \mathrm{O}_{\mathrm{OH}}$ of the same sample. The ranges of $\delta^{34} \mathrm{~S}$ values (Table 1 ) for gypsum, barite, and sulfides are illustrated as lines. The dashed line for the gypsum data indicates that one value $(21.9 \%$ ) extends beyond the main data field for gypsum and beyond the field of the diagram (see Table 1). The $\delta^{34} \mathrm{~S}$ of $\mathrm{H}_{2} \mathrm{~S}$ in equilibrium with sulfate having a $\delta^{34} \mathrm{~S}$ value of $12 \pm 2 \%$ at 150 and $200{ }^{\circ} \mathrm{C}$ is shown at the top of the figure in the rectangles connected by lines.

the water in fluid inclusions from minerals in RGRtype deposits. Calculations to determine the hydrogen and oxygen isotopic composition of water in fluids in equilibrium with jarosite are from Rye and Stoffregen (1995). Natrojarosite forms a complete solid solution with jarosite but has the same hydrogen- and oxygenisotope jarosite-water fractionations (Rye and Stoffregen, 1995).

\section{Discussion of stable-isotope data}

\subsection{Oxygen and sulfur isotopes}

Significant overlap of $\delta^{34} \mathrm{~S}$ values for sulfide, jarosite, and other sulfate minerals is apparent from Fig. 5. The $\delta^{34} \mathrm{~S}$ values of jarosite for all deposits range from $-24.9 \%$ to $7.2 \%$ (VCDT); $\delta^{34} \mathrm{~S}$ values of sulfides range from $-26.6 \%$ to $-3.0 \%$; $\delta^{34} \mathrm{~S}$ values of barite range from $-2.0 \%$ o to $13.1 \%$; and $\delta^{34} \mathrm{~S}$ values of gypsum range from $-11.8 \%$ o to $13.9 \%$, with one sample at $21.9 \%$. The lowest $\delta^{34} \mathrm{~S}$ values for sulfates correspond to similar low values for sulfides in the
Hansonburg deposit. The majority of high $\delta^{34} \mathrm{~S}$ values for sulfates are larger than that of our one sample of the Yeso Formation gypsum (7.1\%), but are similar to those of Permian evaporites in the western US in general (about $12 \pm 2 \%$; Claypool et al., 1980) and are typical of the highest values observed for sulfate in southern New Mexico groundwaters (Witcher, 1995). The $\delta^{34} \mathrm{~S}$ value of the Yeso sample we measured is low for Permian sulfate. Our sample contained small, euhedral quartz crystals whose presence suggests that the sulfate may have been affected by later diagenetic processes. These $\delta^{34} \mathrm{~S}$ values $(12 \pm 2 \%$ ), representative of the vast Permian sulfate reservoir present in groundwater throughout southern New Mexico, are the limiting upper value for sulfur-isotope compositions in jarosite, barite, and gypsum. The range of $\delta^{18} \mathrm{O}_{\mathrm{SO}_{4}}$ values for jarosite is large $(-3.0 \%$ o to $24.8 \%$ ), with values both larger and smaller than those for the sulfate (gypsum) from the Yeso Formation.

As will be discussed, the low $\mathrm{pH}$ required for jarosite formation requires that its $\mathrm{SO}_{4}^{2-}$ be derived from the oxidation of $\mathrm{H}_{2} \mathrm{~S}$. The isotopic composition of hydrothermal jarosite will reflect that of the precursor $\mathrm{H}_{2} \mathrm{~S}$ (the source of jarosite $\mathrm{SO}_{4}^{2-}$ ) unless exchange occurs between the $\mathrm{SO}_{4}^{2-}$ and $\mathrm{H}_{2} \mathrm{~S}$ prior to precipitation of jarosite or unless a significant amount of $\mathrm{SO}_{4}^{2-}$ is also derived from deep or shallow fluids (Rye et al., 1992; Rye and Alpers, 1997). The low $\delta^{34} \mathrm{~S}$ values for jarosite are in the range of values observed for sulfides at Hansonburg and other deposits (Table 1 and Allmendinger, 1975). These low values must reflect those of the precursor $\mathrm{H}_{2} \mathrm{~S}$. Most jarosite samples, however, have intermediate values between those of the precursor $\mathrm{H}_{2} \mathrm{~S}$ and Permian sulfate, probably because of the mixing of isotopically heavy Permian sulfate with isotopically light sulfate derived from the oxidation of $\mathrm{H}_{2} \mathrm{~S}$. The large range of $\delta^{18} \mathrm{O}_{\mathrm{SO}_{4}}$ (and corresponding $\delta^{18} \mathrm{O}_{\mathrm{OH}}$ ) values reflects mainly the range of $\delta^{18} \mathrm{O}$ values of water in variably mixed fluids and the degree of exchange between $\mathrm{SO}_{4}^{2-}$ and water in the basin, as is discussed below.

\section{2. $\Delta^{18} \mathrm{O}_{\mathrm{SO}_{4}}-\mathrm{OH}$ jarosite geothermometry}

Tie lines in Fig. 5 connect $\delta^{18} \mathrm{O}_{\mathrm{SO}_{4}}$ and $\delta^{18} \mathrm{O}_{\mathrm{OH}}$ values from the same jarosite samples. The $\Delta^{18} \mathrm{O}_{\mathrm{SO}_{4}}{ }^{-}$ $\mathrm{OH}$ values can be used as a single-mineral geo- 


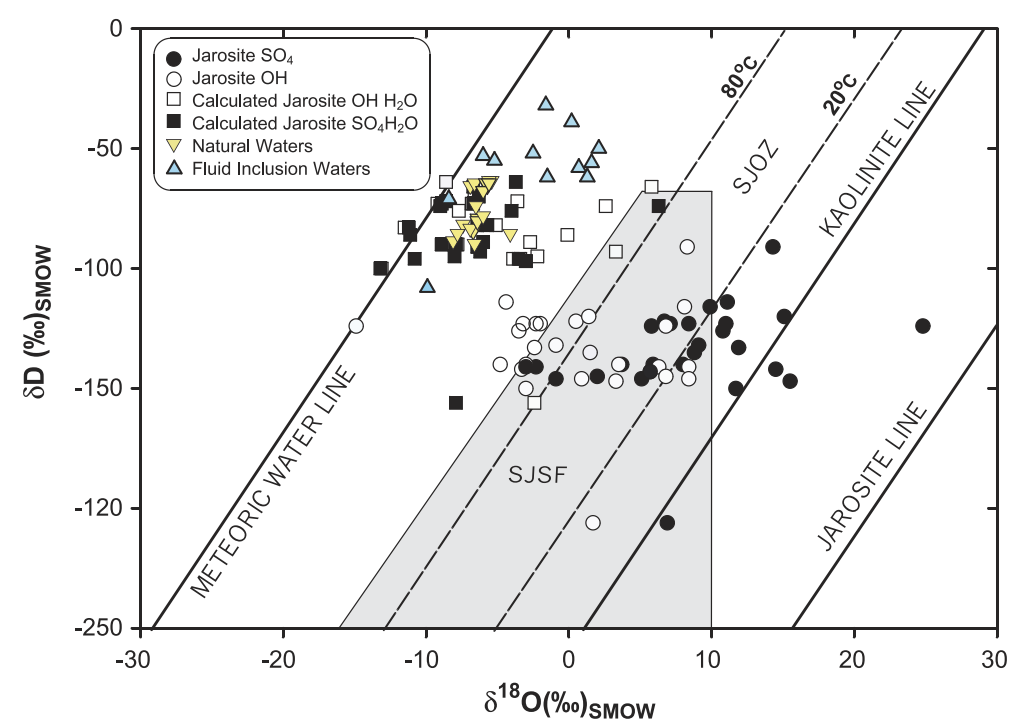

Fig. 6. Diagram of $\delta \mathrm{D}-\delta^{18} \mathrm{O}_{\mathrm{SO}_{4}}-\delta^{18} \mathrm{O}_{\mathrm{OH}}$ for jarosite from southern New Mexico and northern Mexico; $\delta \mathrm{D}_{\mathrm{H}_{2}} \mathrm{O}-\delta^{18} \mathrm{O}_{\mathrm{H}_{2}} \mathrm{O}$ values of parent fluids calculated from both $\delta^{18} \mathrm{O}_{\mathrm{SO}_{4}}-\delta^{18} \mathrm{O}_{\mathrm{OH}}$ data to be in equilibrium with the jarosite at $130{ }^{\circ} \mathrm{C}$ using equations of Rye and Stoffregen (1995); $\delta \mathrm{D}-$ $\delta^{18} \mathrm{O}$ of natural groundwaters in southern New Mexico as determined by Gross (1988), and fluid-inclusion waters determined by Hill et al. (2000). Solid circles=sulfate in jarosite; open circles=hydroxyl in jarosite; solid squares=calculated values for sulfate in equilibrium with waters precipitating jarosite; open squares $=$ calculated values for hydroxyl in equilibrium with waters precipitating jarosite; inverted triangles=natural waters, including springs and geothermal waters of Gross (1988); triangles=fluid-inclusion waters of Hill et al. (2000). The SJOZ (supergene jarosite $\mathrm{OH}$ zone; area between dashed lines) and SJSF (supergene jarosite $\mathrm{SO}_{4}$ field; shaded area) of Rye and Alpers (1997) delineate the range of values expected for supergene jarosite and are presented for reference. The $\delta \mathrm{D}-\delta^{18} \mathrm{O}_{\mathrm{OH}}$ value for the one sample in Table 1 that gave a negative $\Delta^{18} \mathrm{O}_{\mathrm{SO}_{4}}-\mathrm{OH}$ is not plotted.

thermometer provided that $\mathrm{SO}_{4}$ attained equilibrium with the water in the hydrothermal fluid and retrograde exchange did not occur at the $\mathrm{OH}$ site during the waning of mineralization (Rye and Stoffregen, 1995). The average uncertainty of the determinations, as reported by Ebert and Rye (1997), is $\pm 30{ }^{\circ} \mathrm{C}$. Of the 34 jarosite samples analyzed, 21 have $\Delta^{18} \mathrm{O}_{\mathrm{SO}_{4}}-\mathrm{OH}$ between $9.3 \%$ and $13 \%$. This range corresponds to geologically reasonable temperatures between 240 and $80{ }^{\circ} \mathrm{C}$, with a mean of $118^{\circ} \mathrm{C}$ (Table 1 ) on the basis of the experimental fractionations of Rye and Stoffregen (1995). The temperatures calculated from jarosite are well within the range of fluid-inclusion homogenization temperatures determined from fluorite (95 to 346 ${ }^{\circ} \mathrm{C}$, but mostly 120 to $225^{\circ} \mathrm{C}$ ) for the deposits studied (McLemore et al., 1998). A single crystal of jarosite from the Peña Blanca deposit yielded a fluid-inclusion homogenization temperature of $180{ }^{\circ} \mathrm{C}$ (P.C. Goodell, personal communication). A sample of jarosite from the Gumma iron mine (Japan) was analyzed as a monitor for the jarosite $\mathrm{SO}_{4}-\mathrm{OH}$ oxygen isotope thermometer. Jarosite at the Gumma mine is currently precipitating from a warm spring with a measured water temperature of $22^{\circ} \mathrm{C}$ and $\mathrm{pH}=2.8$ (Akai et al., 1997). The $\Delta^{18} \mathrm{O}_{\mathrm{SO}_{4}}-\mathrm{OH}$ temperature from that sample was $30{ }^{\circ} \mathrm{C}$. The $\Delta^{18} \mathrm{O}_{\mathrm{SO}_{4}}-\mathrm{OH}$ values from the other 13 samples yield unrealistically high formation temperatures. Only one determination (TEAA), however, produced a negative temperature, and that sample also produced anomalous sulfur and hydrogen isotopic values. Similar patterns of oxygen equilibrium and disequilibrium between $\mathrm{SO}_{4}$ and $\mathrm{OH}$ sites have been noted for alunite and jarosite from other steam-heated zones in active geothermal systems (Rye et al., 1992; Ebert and Rye, 1997), suggesting that: (1) oxygen isotopic equilibrium was not attained between aqueous sulfate and water in the hydrothermal fluids, (2) retrograde exchange occurred at the $\mathrm{OH}$ site, or (3) difficulties exist with the analyses.

\subsection{Oxygen and hydrogen isotopes}

The $\delta^{18} \mathrm{O}_{\mathrm{SO}_{4}}$ values for all but one of the samples of jarosite range from $-3.0 \%$ o to $15.5 \%$. 
Corresponding $\delta^{18} \mathrm{O}_{\mathrm{OH}}$ values range from $-4.8 \%$ o to $8.4 \%$, and $\delta \mathrm{D}$ values of most samples range from $-206 \%$ to $-91 \%$, with one value at $-266 \%$. A large number of the $\delta \mathrm{D}-\delta^{18} \mathrm{O}_{\mathrm{SO}_{4}}$ values plot outside the supergene-jarosite sulfate field (SJSF) of Rye and Alpers (1997) (Fig. 6). Likewise, a large number of the $\delta \mathrm{D}-\delta^{18} \mathrm{O}_{\mathrm{OH}}$ values plot outside of the dashed lines of the supergene-jarosite $\mathrm{OH}$ field (SJOZ) of Rye and Alpers (1997). These fields represent the range in possible $\delta \mathrm{D}-\delta^{18} \mathrm{O}_{\mathrm{SO}_{4}}-\delta^{18} \mathrm{O}_{\mathrm{OH}}$ values of jarosite in equilibrium with meteoric water in the supergene environment between 20 and $80{ }^{\circ} \mathrm{C}$. These fields serve for reference only. Many samples of hydrothermal jarosite have isotopic compositions that fall within both fields, but few of the compositions of supergene jarosite fall outside of these fields (Rye and Alpers, 1997).

The $\delta^{18} \mathrm{O}_{\mathrm{SO}_{4}}$ values of jarosite are most reliable for calculating the $\delta^{18} \mathrm{O}_{\mathrm{H}_{2}} \mathrm{O}$ of parent fluids. Assuming an average temperature of $130{ }^{\circ} \mathrm{C}$ for jarosite precipitation, the $\delta \mathrm{D}_{\mathrm{H}_{2}} \mathrm{O}-\delta^{18} \mathrm{O}_{\mathrm{H}_{2}} \mathrm{O}$ of the parent fluids for jarosite can be calculated from the experimental fractionation data of Rye and Stoffregen (1995) to be in the range of $-156 \%$ o to $-70 \%$ and $-13.2 \%$ o to $-3.5 \%$ o, respectively. All of the fluid-composition data calculated from $\delta^{18} \mathrm{O}_{\mathrm{SO}_{4}}$ values fall on or to the right of the meteoric water line (Fig. 6). The $\delta \mathrm{D}_{\mathrm{H}_{2}} \mathrm{O}$ value of one sample (for which the $\delta^{18} \mathrm{O}_{\mathrm{SO}_{4}}$ could not be determined) from the Schneider deposit is $-216 \%$. The compositions of most parent fluids for jarosite throughout the southern rift extend from the meteoric water line over the $\delta \mathrm{D}$ range of about $-100 \%$ to $-64 \%$ o in a fashion typical of basin brines as summarized from Hall and Friedman (1963, 1969), Roedder et al. (1963), Clayton et al. (1966), Hitchon and Friedman (1969), Pinckney and Rye (1972), Kharaka et al. (1973), Richardson et al. (1988), and Taylor (1997). These $\delta \mathrm{D}$ values (Fig. 6) are similar to those for geothermal and groundwaters present in the rift area today (Gross, 1988), and are also similar to the values from fluid-inclusion waters in minerals from RGR-type deposits (Hill et al., 2000). The general trends of the data may reflect the mixing of local meteoric water and brines evolved from meteoric water in the basin.

\section{A comparison of ancient and modern waters}

The geochemistry and physical conditions of modern geothermal systems are fairly well documented within the southern Rio Grande Rift (Summers, 1976; Gross, 1988; Witcher, 1995). The New Mexico Geothermal Database (Witcher, 1995) documents geothermal wells and springs that range in temperature from 30.0 to $70.0{ }^{\circ} \mathrm{C}$ with $\mathrm{Na}$ values as high as $1150 \mathrm{mg} \mathrm{L}^{-1}, \mathrm{~K} 174.8 \mathrm{mg} \mathrm{L}^{-1}$, and concentrations of $\mathrm{F}$ up to $14.8 \mathrm{mg} \mathrm{L}^{-1}$. High $\mathrm{Fe}$ concentrations of up to $6 \mathrm{mg} \mathrm{L}^{-1}$ are noted in many cooler and near-surface groundwaters. Sulfate values in geothermal systems range from 33 to $979 \mathrm{mg} \mathrm{L}^{-1}$ and average $223 \mathrm{mg} \mathrm{L}^{-1}$ for 74 analyses, whereas concentrations of $\mathrm{Cl}$ range from 20 to $1685 \mathrm{mg} \mathrm{L}^{-1}$. Hydrogen sulfide has been detected in a number of these systems. The geothermal water compositions are most similar to mixtures of acid-sulfate and neutral chloride waters as defined by Giggenbach (1997). Some of the Rio Grande Rift thermal waters are high in $\mathrm{F}$ ( $\max 14.8 \mathrm{mg} \mathrm{L}^{-1}$, Witcher, 1995) and As (max $0.1 \mathrm{ppm}$, Summers, 1976). Assays of the jarositefluorite ores (McLemore et al., 1996) show As values up to $1500 \mathrm{ppm}$ at the Copiapo deposit.

The calculated isotopic composition of parent fluids that precipitated jarosite in the barite-fluorite deposits is similar to those measured for modern waters, such as those from the Las Cruces geothermal field and modern wells and springs in the Rio Grande Rift (Fig. 6; Gross, 1988). The calculated $\delta \mathrm{D}_{\mathrm{H}_{2}} \mathrm{O}-$ $\delta^{18} \mathrm{O}_{\mathrm{H}_{2}} \mathrm{O}$ values for the jarosite parental fluids and modern waters both plot on a trend extending off the meteoric water line. Typically, $\delta \mathrm{D}_{\mathrm{H}_{2}} \mathrm{O}-\delta^{18} \mathrm{O}_{\mathrm{H}_{2}} \mathrm{O}$ increases are accompanied by increases in salinity and reflect mixing of evolved basinal brine with surface waters. Gross (1988) bracketed the amount of mixing between modern spring waters from the mountainous areas and saline waters in the rift (to determine the relative proportions of each in the Las Cruces geothermal waters) to be between $30 \%$ and $42 \%$ spring-water component. A similar trend (Fig. 6) is observed for the composition of water in fluid inclusions in fluorite from Hansonburg and other deposits in the rift (Hill et al., 2000). Hill et al. (2000) noted that non-horizontal trends in the data from a number of districts did not project back to reasonable values for meteoric waters; consequently, it was 
suggested that the results could be due either to the trapping of fluids in secondary inclusions unrelated to mineralization, or to the mixing of two exchanged waters with different isotopic compositions. Clayton et al. (1966), Hitchon and Friedman (1969), and Kharaka et al. (1973) discussed the isotopic evolution of basin waters that are composed of evolved connate water. The RGR brines, however, contain a significant component derived from the dissolution of Permian evaporites (Böhlke and Irwin, 1992). The salinity of this brine may vary for individual systems, depending on the history of the meteoric water system and the prior removal of salt from the system (Mailloux et al., 1999). Therefore, the trends off the meteoric water line may be due largely to the mixing of meteoric waters with brines.

The trace-element chemistry of the jarosite samples and the similarity of the isotopic composition of their parent fluids to those of modern geothermal waters in the Rio Grande Rift suggest that both fluids have identical origins and that the processes that produced fluorite-barite mineralization in the Rift are still occurring. This continuity of processes is especially evident in the existence of modern geothermal systems north (Rincon) and south (Radium Springs) of the youngest RGR deposit at San Diego Mountain (Witcher, 1998). Both alunite and jarosite occur near San Diego Mountain in rift-basin clastic rocks that are of Plio-Pleistocene age but are as yet undated (Roberts, 2000). We determined a ${ }^{40} \mathrm{Ar} /{ }^{39} \mathrm{Ar}$ age for jarosite of $\sim 0.36 \mathrm{Ma}$ for a veinlet that crosscuts barite mineralization at San Diego Mountain (Table 1 and Lueth et al., 2004). Similar modern systems have produced young, although undated, barite-fluoritesulfide mineralization in Plio-Pleistocene rocks $13 \mathrm{~km}$ north at Rincon, where $>100{ }^{\circ} \mathrm{C}$ geothermal waters occur at depth and are accompanied by sulfide mineralization (Witcher, 1998).

\section{A model for the formation of sour gas hydrothermal jarosite}

A model for the formation of hydrothermal jarosite in barite-fluorite \pm sulfide-jarosite deposits in the Rio Grande Rift can be developed in the context of current ore-genesis models for RGR-type mineralization along rift-valley basins (Allmendinger, 1975; Putnam et al., 1983; Böhlke and Irwin, 1992; McLemore et al., 1998). In these models, deep circulating saline basinal fluids formed from the dissolution of evaporites by meteoric water, possibly with the addition of magmatic components such as HF. These fluids migrated up the basinal boundary faults to favorable horizons (lithologic or hydrologic), dissolved and altered the wallrock, and precipitated the minerals commonly observed in RGR-type deposits. Our model for RGR-type mineralization and the formation of sour gas hydrothermal jarosite (Fig. 7) combines geological information from Clemons (1996) and the hydrologic modeling of Mailloux et al. (1999).

Permian sulfate is abundant in the underlying sedimentary formations and basin fill. Samples of deep brines, trapped in fluid inclusions, have been shown from $\log (\mathrm{Br} / \mathrm{Cl})$ vs. $\log (\mathrm{I} / \mathrm{Cl})$ plots to be derived from the dissolution of this sulfate by deep circulating meteoric water at Hansonburg (Böhlke and Irwin, 1992). At shallow levels, this saline water interfaces with meteoric water recharged in upland margins (Gross, 1988). The Paleozoic rocks contain abundant organic matter, as does the basin fill. When sulfate and organic matter are heated by renewed rifting, $\mathrm{H}_{2} \mathrm{~S}$ is formed from the thermochemical reduction of sulfate.

Formation of jarosite requires special conditions to produce the high ferric iron activities and the low $\mathrm{pH}$ of parent fluids as shown by the stability diagram (Stoffregen, 1993) in Fig. 8. These conditions can occur only in the upper part of hydrothermal systems that receive an abundant supply of atmospheric oxygen to oxidize $\mathrm{H}_{2} \mathrm{~S}$ to $\mathrm{SO}_{4}^{2-}$ and whose host rocks have little inherent or kinetically accessible $\mathrm{pH}$ and $f \mathrm{O}_{2}$ buffering capacity. Jarosite in RGR-type deposits occurs most frequently in limestone host rocks, but only in those deposits where early silicification or clay formation neutralized the $\mathrm{pH}$ buffering capacity of the limestones. Jarosite mineralization is often accompanied by hematite and gypsum assemblages wherein the relative paragenetic sequences are interchangeable. We interpret this feature to represent fluctuating $\mathrm{pH}$ conditions during mineralization (Fig. 8).

As discussed earlier, high $\mathrm{Fe}$ contents are common in groundwater, and high $\mathrm{K}^{+}$and high $\mathrm{Na}^{+}$(for natrojarosite) are common in geothermal waters that tap underlying saline waters throughout the Rift. We 


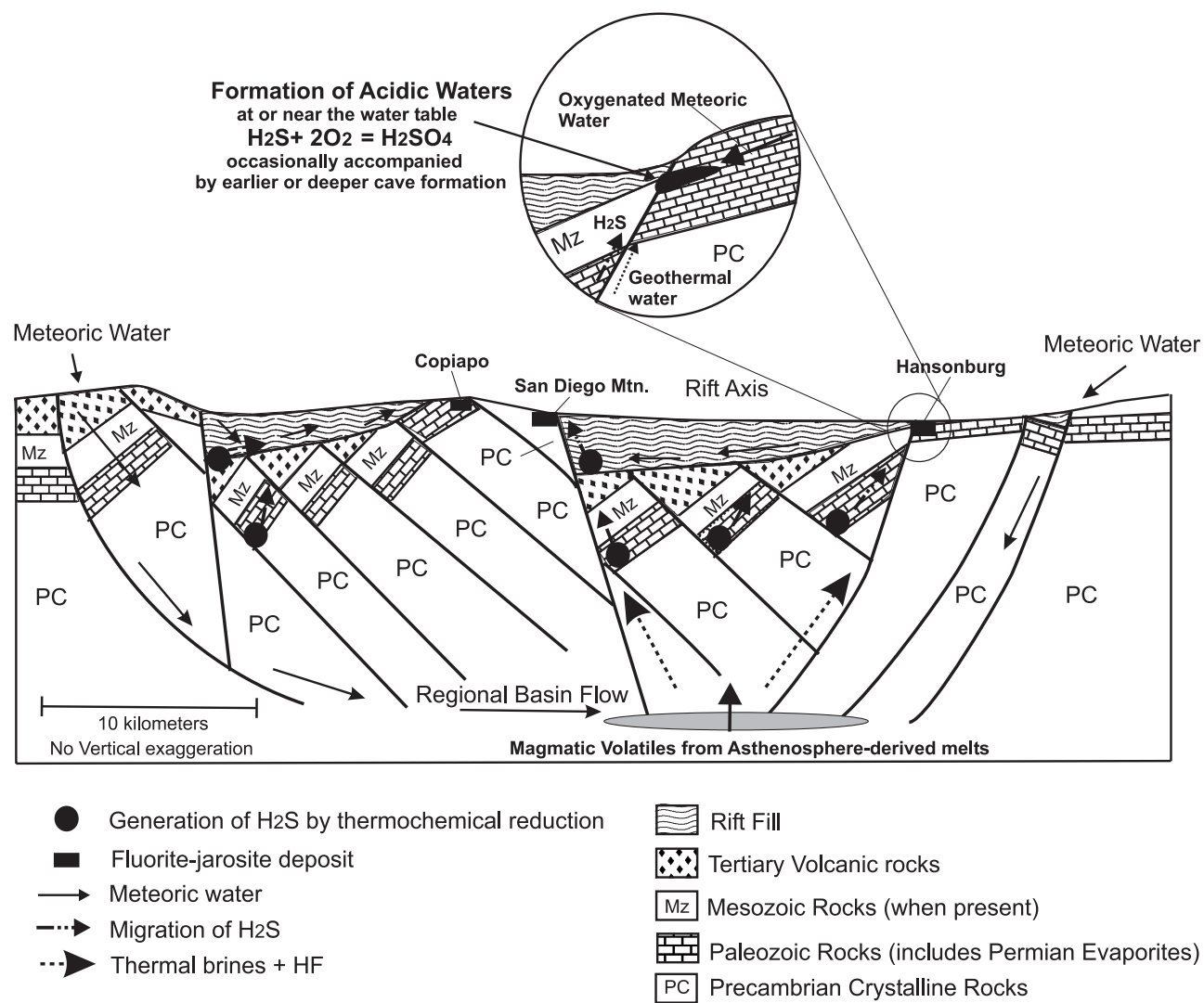

Fig. 7. A schematic model for the formation of hydrothermal "sour gas" jarosite in RGR-type deposits. Geological cross section based on a segment of the Rio Grande Rift presented by Clemons (1996). Hydrologic model based on Mailloux et al. (1999).

can only speculate on the origin of ferric iron at each deposit. However, geochemical mobility of Fe at low $\mathrm{pH}$ is easily accomplished. At the Hansonburg deposits, we noted alteration of shale units, manifested as variability in Fe-oxide coloration, that may indicate a local source of ferric iron mobilized by the acid solutions. Permian arkosic red beds, above and adjacent to the deposits, also may have served as a source for oxidized Fe. Extensive alteration of the Percha Shale (Devonian) in the deposits of the North Franklin Mountains district appears to have been a source of $\mathrm{Fe}$, mobilized by oxidized and acid solutions (Lueth et al., 1998).

The requisite sulfuric acid for jarosite formation is generated by the oxidation of $\mathrm{H}_{2} \mathrm{~S}$, the only potential source for low $\delta^{34} \mathrm{~S}$ values. We suggest three possible sources for this $\mathrm{H}_{2} \mathrm{~S}$ : (1) thermal degradation of organic matter (Goldhaber and Reynolds, 1991), (2) thermochemical reduction of Permian sulfate (Machel et al., 1995), (3) igneous or deep-seated sulfide. Organic matter is abundant in the Paleozoic host rocks and in the basin sedimentary rocks, and hydrocarbon 'shows' are not uncommon in gas- and oil-well boreholes, some of which produce $\mathrm{H}_{2} \mathrm{~S}$-bearing geothermal waters (Summers, 1976). Some igneous sulfide is likely to be derived from deep-seated sources, but by far the largest reservoir of sulfur is the Permian evaporites of the Yeso and San Andres formations. Thus, $\mathrm{H}_{2} \mathrm{~S}$ of igneous origin, or from the thermal degradation of organic matter or the thermochemical reduction of sulfate, would be isotopically buffered by exchange with Permian sulfate deep in the rift basins. Exchange between $\mathrm{H}_{2} \mathrm{~S}$ and $\mathrm{SO}_{4}^{2-}$ would likely be rapid because of presumed low $\mathrm{pH}$ in the basinal fluids (Ohmoto and Lasaga, 1982), possibly due to the presence of deep-seated HF. For example, as shown in Fig. 5, the $\delta^{34} \mathrm{~S}$ of $\mathrm{H}_{2} \mathrm{~S}$ in equilibrium with Permian sulfate $\left(\delta^{34} \mathrm{~S}=12 \%\right.$ ) would be $-17 \%$ at 


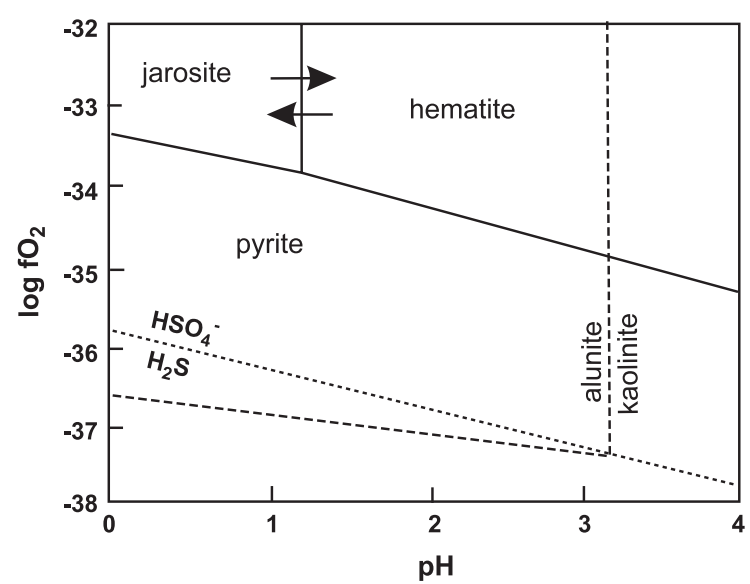

Fig. 8. Stability field of jarosite at $200{ }^{\circ} \mathrm{C}$ and 100 bars, the upper limit of mineralization temperatures as reported in this study. Arrows represent inferred variation of $\mathrm{pH}$ during overlapping or oscillating jarosite-hematite-gypsum mineralization. Diagram modified from Stoffregen (1993) for $\log m \sum S=-0.5$ and $\log m \mathrm{~K}^{+}=-1.5 \mathrm{~K}$.

$200{ }^{\circ} \mathrm{C}$ and $-24 \%$ at $150{ }^{\circ} \mathrm{C}$, reasonable temperatures in the deep basin during renewed rifting. At $200{ }^{\circ} \mathrm{C}$, equilibrium between $\mathrm{H}_{2} \mathrm{~S}$ and $\mathrm{SO}_{4}^{2-}$ will be reached in low-pH fluids in less than 200 days (Ohmoto and Lasaga, 1982). $\mathrm{H}_{2} \mathrm{~S}$ with less negative $\delta^{34} \mathrm{~S}$ values could reflect exchange at higher temperatures or less equilibration with Permian sulfate. The intermediate $\delta^{34} \mathrm{~S}$ values for jarosite, barite, and gypsum are consistent with mixing of $\mathrm{SO}_{4}^{2-}$ from the oxidation of isotopically light $\mathrm{H}_{2} \mathrm{~S}$ and that from isotopically heavy Permian sulfate.

The $\delta \mathrm{D}_{\mathrm{H}_{2}} \mathrm{O}$ and $\delta^{18} \mathrm{O}_{\mathrm{H}_{2}} \mathrm{O}$ data for parent jarosite fluids (Fig. 6) also suggest mixing. One end-member fluid is local meteoric water. As discussed below, the other is exchanged or evolved brine from deep in the basin and with a possible magmatic gas (HF) component. McMillan (1998) documented a region of asthenosphere-derived melts in the Rio Grande Rift that is correlative to the distribution of fluorite deposits (Fig. 9). The mantle has been noted to be a ready source of fluorine in early models of fluoritedeposit genesis in the region (Van Alstine, 1976). Keller et al. (1990) discussed additional evidence for magmatic influences and stated that modern heat flow is too high to be caused by extension alone; Keller et al. postulated that extensive crustal thickening, by intrusions into the lower crust, is necessary to account for the observed heat flow. However, heated and deeply circulating fluids are also capable of deriving $\mathrm{Ba}$ and $\mathrm{F}$ from rocks altered at depth (Putnam et al., 1983). A-type Proterozoic granites, which comprise the basement rocks of this area, are known to contain primary igneous fluorite (Shannon, 1994) and would provide a ready source of the $\mathrm{Ba}, \mathrm{F}$, and $\mathrm{Pb}$ in the deposits. However, the limestone-cave formation in the plumbing system of some RGR-type deposits indicates a low $\mathrm{pH}$ for some deep basinal fluids. Plumlee et al. (1995) showed that the addition of igneous volatiles is required to produce low-pH fluids in fluorite depositional systems in the IllinoisKentucky fluorspar district because the leaching of basement granitoid rocks would produce an insufficient amount of $\mathrm{F}$ to form the deposits according to their geochemical models.

The precipitation of jarosite within these deposits probably occurred when $\mathrm{pH}$ was lowered by the oxidation of $\mathrm{H}_{2} \mathrm{~S}$ until jarosite saturation was reached

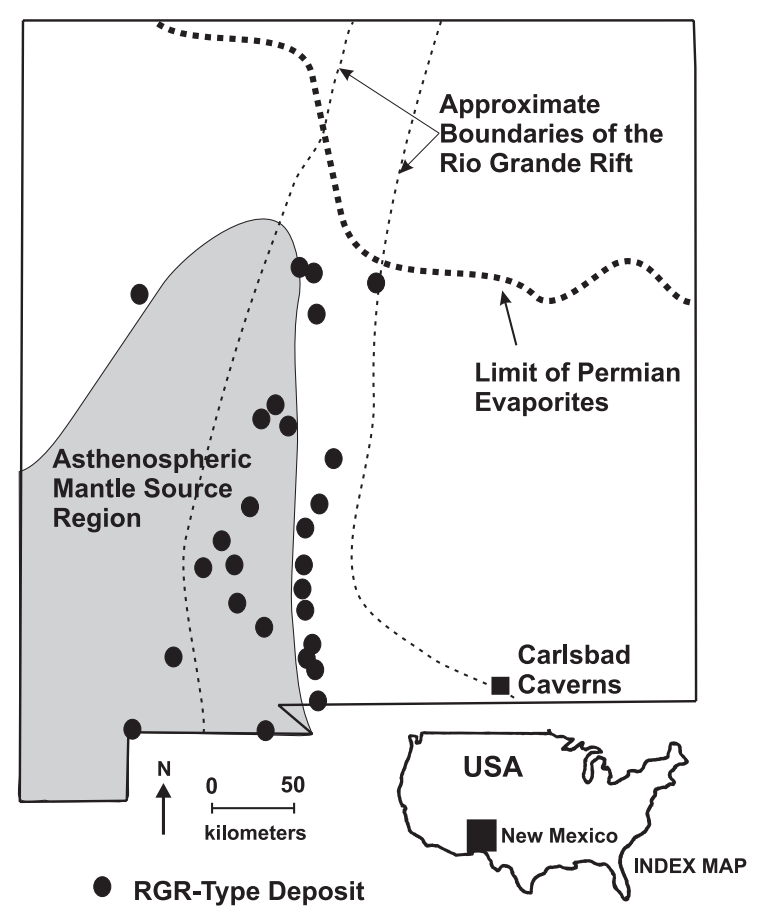

Fig. 9. The distribution of asthenosphere-derived melts involved in Rio Grande Rift magmatism (McMillan, 1998) and RGR-type deposits in southern New Mexico (McLemore et al., 1998). Permian evaporites are limited to the area south of the bold dashed line (Weber and Kottlowski, 1959). 
in Fe- and K-bearing fluids (Fig. 8). This scenario would result in limited areas of jarosite formation within these deposits where sites of $\mathrm{H}_{2} \mathrm{~S}$ oxidation were isolated from reactive host rocks. Most jarosite occurrences are limited to late-stage crosscutting veinlets except at Copiapo and Margaritas. At Copiapo, jarosite replaced earlier hematite in wallrocks. At Margaritas, jarosite replaced alunite (that replaced feldspar in the volcanic host rock), similar to that described at Goldfield, Nevada by Keith et al. (1979).

\section{Cave formation in RGR-type deposits}

Caves are a common occurrence in RGR-type deposits that are hosted in limestones, such as at Hansonburg and Copiapo. At Hansonburg, some of the caves are mineralized and demonstrate many of the characteristics of sulfuric acid speleogenesis described by Hill (1995) for Carlsbad Caverns, New Mexico. However, silicification of the host rocks is pervasive at most RGR-type deposits in contrast to a relative lack of wallrock alteration at Carlsbad. This difference likely reflects the absence of hydrothermal solutions at Carlsbad, where the caves were formed solely by the acid solutions generated by $\mathrm{H}_{2} \mathrm{~S}$ interaction with oxidized groundwater (Hill, 1995). At the Copiapo jarosite mine, the caves are unmineralized and occur deep in the plumbing system below the level of mineralization, as is also common in the Illinois-Kentucky fluorspar district (Plumlee et al., 1995). The exceptionally low $\delta^{34} \mathrm{~S}$ values of about $-25 \%$ o for some of the RGR jarosite are similar to those observed for Carlsbad Caverns alunite (some with very low $\delta^{34} \mathrm{~S}$ values according to Polyak and Güven, 1996). The presence of copious amounts of gypsum accompanied by minor pyrite in many RGRtype deposits also suggests that cave formation occurred during mineralization in some deposits but always before jarosite formation. Gypsum with exceptionally low $\delta^{34} \mathrm{~S}$ values in some caves (Polyak and Güven, 1996) likely formed from aqueous sulfate derived from the oxidation of the same isotopically light $\mathrm{H}_{2} \mathrm{~S}$ as the aqueous sulfate required for the formation of jarosite in the RGR-type deposits. In such cases, the oxidation of $\mathrm{H}_{2} \mathrm{~S}$ was probably important in cave formation and jarosite did not form until the host rocks were sufficiently altered to destroy their $\mathrm{pH}$-buffering capacity. In other deposits, it seems that fluids from depth already had a $\mathrm{pH}$ low enough to dissolve limestone prior to the oxidation of the $\mathrm{H}_{2} \mathrm{~S}$ that led to the formation of jarosite. Most limestonehosted deposits lie immediately above Proterozoic granite and gneiss; thus, acid solutions did not have to traverse long distances through reactive rocks.

\section{Tectonic implications of the sour gas jarosite model}

Sour gas hydrothermal jarosite in the study area has formed over a time span from $\sim 10 \mathrm{Ma}$ to the present. This continuum of ages is punctuated by episodic events within the rift that are reflected by similar ages (Fig. 4) among widely separated deposits, e.g., the EPM deposit (7.8 Ma) in the Potrillo Mtn. district, and the Sunshine No. 6 mine (7.94 Ma) in the Hansonburg district. In addition, except for two deposits at Hansonburg (e.g., Sunshine No. 6), older ages are concentrated in the southern portion of the study area (Peña Blanca, $11 \mathrm{Ma}$; Potrillo Mountains, 7.8 Ma). A similar pattern can be discerned along a transect from near the eastern margin (Bishop Cap; Bluestar, 5.4 Ma) to the axis of the rift (San Diego Mountain, 0.36 Ma). These age relationships are consistent with models that postulate the rift opened from south to north and that most magmatism is concentrated along the axis of the rift.

Early workers (Keller et al., 1990) defined a twophase history of extension and volcanism during the history of the rift. Early extension occurred from 30 to 15 Ma. This early phase is characterized by calcalkaline magmatism. Following a lull in magmatism, renewed extension and segmentation of the rift into modern, narrow blocks occurred from 10 to $3 \mathrm{Ma}$. This renewed tectonism is characterized by alkaline magmatism, mainly alkali-olivine basalt, which has intensified over the last 5 my (Keller et al., 1990). Recent research points to a more continuous extension in the rift over the last 30 my (Keller and Cather, 1994; Mailloux et al., 1999), although the patterns of magmatism are the same for either model. The distribution of ages of hydrothermal jarosite from the RGR-type deposits corresponds to tectonic episodes within specific portions of the rift during this 
period of alkali magmatism, and by inference, reflects periods during which fluorine was introduced into the rift. Modern heat-flow data cannot be explained simply in terms of extension and require crustal thickening by intrusions into the lower crust (Keller et al., 1990). This regime of high heat flow provides the engine for the formation of RGR-type deposits during the periods reflected by the ages of the jarosite. Furthermore, the period of renewed tectonism began around $12 \mathrm{Ma}$ and continues to this day. The common ages of RGR-type mineralization may indicate that episodes of tectonic activity either occurred episodically over large areas of the rift or, as proposed by Mailloux et al. (1999), episodic hydrologic events occurred during continuous tectonic activity.

Two or three of the ages of the hydrothermal jarosite from the RGR-type deposits approximately coincide with ${ }^{40} \mathrm{Ar} /{ }^{39} \mathrm{Ar}$ ages of $\sim 6.3,5.2$, and possibly $\sim 4.0 \mathrm{Ma}$ reported by Polyak et al. (1998) for alunite from the Carlsbad Caverns system. Polyak et al. observed a bimodal distribution in the elevation of the caves at Carlsbad, and attributed it to two periods of increased precipitation around 12 to $11 \mathrm{Ma}$ and 6 to $4 \mathrm{Ma}$. The coincidence between the age data for Carlsbad alunite and our RGR-type jarosite suggests that the change in elevation at Carlsbad was more likely related to significant pulses of tectonic activity and associated uplift on the eastern margin of the rift.

The Ar age data of the hydrothermal jarosite in the RGR-type deposits can also be used to calibrate uplift rates along boundary faults in the Rio Grande Rift. Lueth et al. (1998), using assumptions for mineralization depth that apply to nearby deposits, determined uplift rates at the Copiapo deposit to be $152 \mathrm{~m} \mathrm{my}^{-1}$ over the last $5 \mathrm{my}$, corresponding to similar estimates that Kelly and Chapin (1997) obtained by utilizing fission-track analysis of apatite.

\section{Conclusions}

A new type of steam-heated hydrothermal jarosite has been recognized. This jarosite type formed late in the paragenesis of fluorite-barite deposits that were generated by mixing of heated sulfate, potassium, and possibly iron bearing basinal brines (with possible additions of deep-seated HF) and meteoric water. The requisite sulfuric acid for the jarosite was produced by the atmospheric oxidation of $\mathrm{H}_{2} \mathrm{~S}$ that separated from hydrothermal fluids derived from the basin. The $\mathrm{H}_{2} \mathrm{~S}$ was probably derived in the basin largely as sour gas from the thermochemical reduction of Permian sulfate in an organic-rich sedimentary basin during renewed periods of tectonic activity. The $\mathrm{H}_{2} \mathrm{~S}$ had exceptionally low $\delta^{34} \mathrm{~S}$, probably as a result of exchange at temperatures of $\sim 150$ to $200{ }^{\circ} \mathrm{C}$ with the more abundant Permian $\left(\delta^{34} \mathrm{~S}=12 \pm 2 \%\right.$ o $) \mathrm{SO}_{4}^{2-}$. The formation of limestone caves as a precursor to mineralization in some areas indicates that the deep brines were initially low in $\mathrm{pH}$, thus supporting the proposition that addition of HF occurred during rifting. Sulfuric acid speleogenesis due to oxidation of $\mathrm{H}_{2} \mathrm{~S}$ also seems to have occurred at some of the deposits.

The systems that produced these deposits were sufficiently long-lived to form small to substantial fluorite-barite \pm sulfide-jarosite deposits in limestone host rocks. One deposit apparently formed over a period of $0.8 \mathrm{my}$, as indicated by ${ }^{40} \mathrm{Ar} /{ }^{39} \mathrm{Ar}$ age dating of jarosite on opposite ends of the paragenetic sequence of mineralization. Apparent common age groupings of deposits may correspond to the inferred regional tectonic or hydrologic episodes defined by previous workers. Some of these episodes are also recognized as individual periods of mineralization within the larger deposits (e.g., Hansonburg).

Jarosite that formed in RGR-type deposits can be dated precisely and can be used to trace the isotopic values (e.g., $\delta \mathrm{D}_{\mathrm{H}_{2} \mathrm{O}}$ ) of parent fluids. When the $\delta \mathrm{D}_{\mathrm{H}_{2} \mathrm{O}}$ of meteoric water can be determined from the jarosite, a record of the interaction between tectonism and climate becomes available. Detailed studies of individual deposits have the greatest potential for gleaning paleoclimate information encoded in sour gas jarosite at the time of its formation. Our model for the formation of sour gas jarosite has immediate application to studies of water quality and supply in the region, especially with respect to natural trace-element contamination (e.g., As and F) and incursion of saline geothermal waters into potable aquifers in proximity to major faults near structural highs.

\section{Acknowledgments}

The constructive reviews by Robert Seal, Michele Tuttle, and an anonymous reviewer are gratefully 
acknowledged. We thank Cyndi Kester for help with the stable-isotope analyses, and are grateful to Marty Goldhaber for an earlier review of this paper. We appreciate discussions with Roger Stoffregen concerning the mineralogical stability of jarosite and Jim Witcher pertaining to modern geothermal systems in the rift. We also benefited from discussions with Phil Goodell about hydrothermal jarosite at the Copiapo and the Peña Blanca deposits. We also acknowledge the assistance of Richard Esser in the ${ }^{40} \mathrm{Ar} /{ }^{39} \mathrm{Ar}$ analysis. [PD]

\section{References}

Akai, J., Kawamoto, K., Akai, K., Nakano, S., 1997. Biogenic contribution to the formation of iron ore in Gumma Iron Mine, central Japan. Proc. 30th Int. Geol. Congr., vol. 9, pp. 199-208.

Allmendinger, R.J., 1975. A model for ore-genesis in the Hansonburg mining district, New Mexico. PhD thesis, New Mexico Inst. Mining and Technology, Socorro, New Mexico.

Alpers, C.N., Rye, R.O., Nordstrom, D.K., White, L.D., King, B.S., 1992. Chemical, crystallographic and stable isotope properties of alunite and jarosite from acid-hypersaline lakes. Chem. Geol. 96, 203-226.

Berliner, M.H., 1949. The Copiapo Jarosite mine, north Franklin Mountains mining district, Doña Ana County, New Mexico. U.S. Bur. Mines Examination Rep. 7 pp.

Böhlke, J.K., Irwin, J.J., 1992. Brine history indicated by argon, krypton, chlorine, bromine, and iodine analysis of fluid inclusions from the Mississippi Valley type lead-fluorite-barite deposits at Hansonburg, New Mexico. Earth Planet. Sci. Lett. $110,51-66$.

Claypool, G.E., Holser, W.T., Kaplan, I.R., Sakai, H., Zak, I., 1980. The age curves of sulfur and oxygen isotopes in marine sulfate and their mutual interpretations. Chem. Geol. 28, 199-260.

Clayton, R.N., Friedman, I., Graf, D.L., Mayeda, T.K., Meents, W.F., Shimp, N.F., 1966. The origin of saline formation waters: 1. Isotopic composition. J. Geophys. Res. 71, 3869-3882.

Clemons, R.E., 1996. Cross sections A through D. In: Kelley, R.W. (Ed.), New Mexico Geological Highway Map. New Mexico Geol. Soc., Socorro, New Mexico.

Deino, A., Potts, R., 1992. Age probability spectra for examination of single-crystal ${ }^{40} \mathrm{Ar} /{ }^{39} \mathrm{Ar}$ dating results: examples from Olorgesailie, Southern Kenya Rift. Quat. Int. 7/8, $81-89$.

Dunham, K.C., 1935. The geology of the Organ Mountains. Bull.N.M. Bur. Mines Mineral Resour. 11, 1-172.

Ebert, S.W., Rye, R.O., 1997. Secondary precious metal enrichment by steam-heated fluids in the Crofoot-Lewis hot spring goldsilver deposit and relation to paleoclimate. Econ. Geol. 92, $578-600$.

Giesemann, A., Jager, H.J., Norman, A.L., Krouse, H.R., Brand, W.A., 1994. On-line sulfur isotope determination using an elemental analyzer coupled to a mass spectrometer. Anal. Chem. 66, 2816-2819.

Giggenbach, W.F., 1997. The origin and evolution of fluids in magmatic-hydrothermal systems. In: Barnes, H.L. (Ed.), Geochemistry of Hydrothermal Ore Deposits, 3rd ed. Wiley, New York, pp. 737-796.

Goldhaber, M.B., Reynolds, R.L., 1991. Relations among hydrocarbon reservoirs, epigenetic sulfidization, and rock magnetization: examples from the south Texas coastal plain. Geophysics 56, 748-757.

Goodell, P.C., Lueth, V.W., Peters, L., Reyes-Cortes, I., 1999. Giant jarosite crystals from the Peña Blanca uranium district, Chihuahua, Mexico. Mineral. Rec. 30, 85.

Gross, J.T., 1988. A hydrological investigation of the Las Cruces geothermal field. MS Thesis, New Mexico State Univ. Las Cruces, New Mexico.

Hall, W.E., Friedman, I., 1963. Composition of fluid inclusions, cave-in-rock fluorite district, Illinois, and Upper Mississippi Valley zinc-lead district. Econ. Geol. 58, 886-911.

Hall, W.E., Friedman, I., 1969. Oxygen and carbon isotopic composition of ore and host rock of selected Mississippi Valley deposits. U.S. Geol. Surv. Prof. Pap. 650-C, C140-C148.

Henry, C.D., Price, J.G., McDowell, F.W., 1983. Presence of the Rio Grande rift in west Texas and Chihuahua. El Paso Geol. Soc. 1983 Field Conf. Guidebook, pp. 108-118.

Hill, C., 1995. Sulfur redox reactions: hydrocarbons, native sulfur, Mississippi Valley-type deposits and sulfuric acid karst in the Delaware Basin, New Mexico and Texas. Environ. Geol. 25, 16-23.

Hill, G.T., Campbell, A.R., Kyle, P.R., 2000. Geochemistry of southwestern New Mexico fluorite occurrences: implications for precious metals exploration in fluorite-bearing systems. J. Geochem. Explor. 68, 1-20.

Hitchon, B., Friedman, I., 1969. Geochemistry and origin of formation waters in the western Canada sedimentary basin: I. Stable isotopes of hydrogen and oxygen. Geochim. Cosmochim. Acta 33, 1321-1349.

Jenkins, D.A., 1977. Geological evaluation of the EPM mining claims, East Potrillo Mountains, Doña Ana County, New Mexico. MS Thesis, New Mexico Instit. Mining and Technology, Socorro, New Mexico.

Keith, W.J., Calk, L., Ashley, R.P., 1979. Crystals of coexisting alunite and jarosite, Goldfield, Nevada. US Geol. Surv. Shorter Cont. Mineral. Petrol., C1-C5.

Keller, G.R., Cather, S.M., 1994. Introduction. In: Keller, G.R., Cather, S.M. (Eds.), Basins of the Rio Grande Rift: Structure, Stratigraphy, and Tectonic Setting, Geol. Soc. Am. Spec. Pap. 291, pp. $1-3$.

Keller, G.R., Morgan, P., Seager, W.R., 1990. Crustal structure, gravity anomalies and heat flow in the southern Rio Grande rift and their relationship to extensional tectonics. Tectonophysics 174, $21-37$.

Kelley, S.A., Chapin, C.E., 1997. Cooling histories of mountain ranges in the southern Rio Grande rift based on apatite fissiontrack analysis - a reconnaissance survey. N.M. Geol. 19, 1-14.

Kharaka, Y.K., Berry, F.A.F., Friedman, I., 1973. Isotopic composition of oil-field brines from Kettleman North Dome, Cal- 
ifornia, and their geological implications. Geochim. Cosmochim. Acta 37, 1899-1903.

Lueth, V.W., Goodell, P.C., 1996. A remarkable deposit of jarosite: the product of rift basin dewatering. Abstr. Programs-Geol. Soc. Am. 28, A-210.

Lueth, V.W., Heizler, M.T., 1997. ${ }^{40} \mathrm{Ar} /{ }^{39} \mathrm{Ar}$ age and origin of jarosite mineralization at the Hansonburg district, New Mexico. N.M. Geol. 19, 51.

Lueth, V.W., Goodell, P.C., Heizler, M.T., 1998. Geochemistry, geochronology, and tectonic implications of jarosite mineralization in the northern Franklin Mountains, Doña Ana County, New Mexico. Guideb. - New Mexico Geol. Soc. 49, 309-315.

Lueth, V.W., Rye, R.O., Peters, L., 1999. Age and stable isotope geochemistry of hydrothermal jarosite at the Copiapo jarosite mine, New Mexico. Abstr. Programs-Geol. Soc. Am. 31, A-403.

Lueth, V.W., Rye, R.O., Peters, L., 2000. The origin and natural destruction of an ore deposit as recorded by jarosite: Hansonburg Mining District, New Mexico. Abstr. Programs-Geol. Soc. Am. 32, A-109.

Lueth, V.W., Rye, R.O., Peters. L. 2004. ${ }^{40} \mathrm{Ar}{ }^{39} \mathrm{Ar}$ data repository for "Sour Gas" hydrothermal jarosite: Ancient to modern acidsulfate mineralization in the southern Rio Grande Rift. New Mexico Bur. Geol. Mineral Resour. Argon Open-file Rep. OFAR 22, 1-41.

Machel, H.G., Krouse, H.R., Sassen, R., 1995. Products and distinguishing criteria of bacterial and thermochemical sulfate reduction. Appl. Geochem. 10, 373-389.

Mailloux, B., Person, M., Kelley, S., Dunbar, N., Cather, S., Strayer, L., Hudleston, P., 1999. Tectonic controls on the hydrogeology of the Rio Grande Rift, New Mexico. Water Resour. Res. 35, $2641-2659$.

McLemore, V.T., Lueth, V.W., 1996. Carbonate-hosted lead-zinc deposits in New Mexico. In: Sangster, D.F. (Ed.), Carbonate Hosted Lead-Zinc Deposits, Soc. Econ. Geol. Spec. Pub. 4, pp. 264-276.

McLemore, V.T., Sutphin, D.M., Hack, D.R., Pease. T.C. 1996. Mining history and mineral resources of the Mimbres resource area, Doña Ana, Luna, Hidalgo, and Grant counties, New Mexico. New Mexico Bur. Mines Mineral Resour. Open-file Rep. OF-424, 251 pp.

McLemore, V.T., Giordano, T.H., Lueth, V.W., Witcher, J.C., 1998. Origin of barite-fluorite-galena deposits in the southern Rio Grande Rift, New Mexico. Guideb.-New Mexico Geol. Soc. 49, 251-263.

McMillan, N.J., 1998. Temporal and spatial magmatic evolution of the Rio Grande Rift. Guideb.-New Mexico Geol. Soc. 49, $107-116$.

Norman, D.I., Ting, W., Putnam, B.R., Smith, R.W., 1985. Mineralization of the Hansonburg Mississippi-Valley-type deposit, New Mexico: insight from composition of gases in fluid inclusions. Can. Mineral. 23, 353-368.

Ohmoto, H., Lasaga, A.C., 1982. Kinetics of reactions between aqueous sulfates and sulfides in hydrothermal systems. Geochim. Cosmochim. Acta 46, 1727-1745.

Pinckney, D.M., Rye, R.O., 1972. Variation of $\mathrm{O}^{18} / \mathrm{O}^{16}, \mathrm{C}^{18} / \mathrm{C}^{12}$, texture and mineralogy in altered limestone in the Hill Mine, Cave-in-Rock District, Illinois. Econ. Geol. 67, 1-18.
Plumlee, G.S., Goldhaber, M.B., Rowan, E.L., 1995. The potential role of magmatic gases in the genesis of Illinois-Kentucky fluorspar deposits: implications from chemical reaction path modeling. Econ. Geol. 90, 999-1011.

Polyak, V.J., Güven, N., 1996. Alunite, natroalunite, and hydrated halloysite in Carlsbad Cavern and Lechuguilla Cave, New Mexico. Clays Clay Miner. 44, 843-850.

Polyak, V.J., McIntosh, W.C., Güven, N., Provencio, P., 1998. Age and origin of Carlsbad Cavern and related caves from ${ }^{40} \mathrm{Ar} /{ }^{39} \mathrm{Ar}$ of alunite. Science 279, 1919-1922.

Putnam, B.R., Norman, D.I., Smith, R.W., 1983. Mississippi Valleytype lead-fluorite-barite deposits of the Hansonburg mining district. Guideb.-New Mexico Geol. Soc. 34, 253-259.

Richardson, C.K., Rye, R.O., Wasserman, M.D., 1988. The chemical and thermal evolution of the fluids in the Cave-inRock fluorspar district, Illinois: stable isotope systematics at the Deardorff Mine. Econ. Geol. 83, 765-783.

Roberts, D.E., 2000. The cementation and hydrogeology of two fossil geothermal systems hosted within the Camp Rice Formation at Box Canyon and San Diego Mountain, Doña Ana County, New Mexico. New Mexico Geol. Soc. Ann. Meet. Proc. Vol., 13.

Roedder, E., Ingram, B., Hall, W.E., 1963. Studies of fluid inclusions: III. Extraction and quantitative analysis of inclusions in the milligram range. Econ. Geol. 58, 353-374.

Roedder, E., Heyl, A.V., Creel, J.P., 1968. Environment of ore deposition at the Mex-Tex deposits, Hansonburg district, New Mexico, from studies of fluid inclusions. Econ. Geol. 58, 353-374.

Rye, R.O., Alpers, C.N. 1997. The stable isotope geochemistry of jarosite. U.S. Geol. Surv. Open-File Rep., 88-97.

Rye, R.O., Stoffregen, R.E., 1995. Jarosite-water oxygen and hydrogen isotope fractionations: preliminary experimental data. Econ. Geol. 90, 2336-2342.

Rye, R.O., Bethke, P.M., Wasserman, M.D., 1992. The stable isotope geochemistry of acid sulfate alteration. Econ. Geol. 87, $225-262$.

Rye, R.O., Bethke, P.M., Lanphere, M.A., Steven, T.A., 2000. Neogene geomorphic and climatic evolution of the central San Juan Mountains, Colorado, K/Ar age and stable isotope data on supergene alunite and jarosite from the Creede mining district. In: Bethke, P.M., Hay, R. (Eds.), Ancient Lake Creede: Its Volcano-Tectonic Setting, History of Sedimentation, and Relation to Mineralization in the Creede Mining District, Geol. Soc. Am. Spec. Pap. 346, pp. 95-103.

Shannon, W., 1994. Petrogenesis of middle Proterozoic alkaline granitic rocks, Franklin Mountains, West Texas, PhD thesis, Univ. Texas, El Paso, Texas.

Sillitoe, R.H., McKee, E.H., 1996. Age of supergene oxidation and enrichment in the Chilean porphyry copper province. Econ. Geol. 91, 164-179.

Stoffregen, R.E., 1993. Stability relations of jarosite to natrojarosite at $150-250{ }^{\circ} \mathrm{C}$. Geochim. Cosmochim. Acta 57, 2417-2429.

Summers, W.K., 1976. Catalog of thermal waters in New Mexico. N.M. Bur. Mines Miner. Resour. Hydrologic 4, 1-80.

Taylor Jr., H.P., 1997. Oxygen and hydrogen isotope relationships in hydrothermal mineral deposits. In: Barnes, H.L. (Ed.), Geo- 
chemistry of Hydrothermal Ore Deposits, 3rd ed. Wiley, New York, pp. 229-302.

Van Alstine, R.E., 1976. Continental rifts and lineaments associated with major fluorspar districts. Econ. Geol. 71, 977-987.

Vasconcelos, P.M., Brimhall, G.H., Becker, T.A., Renne, P.R., 1994. ${ }^{40} \mathrm{Ar} /{ }^{39} \mathrm{Ar}$ analysis of supergene jarosite and alunite: Implications to the paleoweathering history of the western USA and West Africa. Geochim. Cosmochim. Acta 58, 401-420.

Wasserman, M.D., Rye, R.O., Bethke, P.M., Arribas. A. 1992. Methods for separation and total isotope analysis of alunite. U.S. Geol. Surv. Open-File Rep., 92-99.
Weber, R.H., Kottlowski, F.E., 1959. Gypsum resources of New Mexico. Bull.-N.M. Bur. Geol. Mineral Resour. 68, 1-68.

Witcher, J.C., 1988. Geothermal resources of southwestern New Mexico and southeastern Arizona. Guideb.-New Mexico Geol. Soc. 39, 191-197.

Witcher, J.C., 1995. New Mexico geothermal database 1995. Southwest Technol. Develop. Inst. New Mexico State Univ, pp. $1-59$.

Witcher, J.C., 1998. The Rincon SLH1 geothermal well. Guideb.New Mexico Geol. Soc. 49, 35-38. 